\title{
CARACTERIZAÇÃO DE PROTEASES EXTRACELULARES PRODUZIDAS POR Xylella fastidiosa DE CITROS E VIDEIRA
}

\section{LUCIANA MARIA FEDATTO}

Dissertação apresentada ao curso
Interunidades ESALQ/CENA-USP, para
obtenção do título de Mestre; área de
$\begin{aligned} & \text { concentração: } \\ & \text { Agroecossistemas. }\end{aligned}$

\section{PIRACICABA}

Estado de São Paulo - Brasil

Novembro - 2004 


\title{
CARACTERIZAÇÃO DE PROTEASES EXTRACELULARES PRODUZIDAS POR Xylella fastidiosa DE CITROS E VIDEIRA
}

\section{LUCIANA MARIA FEDATTO}

Farmacêutica

Orientadora: Prof. Dra. SIU MUI TSAI

\begin{abstract}
Dissertação apresentada a Universidade de São Paulo curso Interunidades ESALQ/CENA-USP, para obtenção do título de Mestre; Área de concentração: Ecologia de Agroecossistemas.
\end{abstract}

PIRACICABA

Estado de São Paulo - Brasil

Novembro - 2004 


\section{Dados Internacionais de Catalogação na Publicação (CIP) DIVISÃO DE BIBLIOTECA E DOCUMENTAÇÃO - ESALQ/USP}

Fedatto, Luciana Maria

Caracterização de proteases extracelulares produzidas por Xylella fastidiosa de citros e videira / Luciana Maria Fedatto. - - Piracicaba, 2004.

67 p. : il.

Dissertação (Mestrado) - - Escola Superior de Agricultura Luiz de Queiroz, 2004.

Bibliografia.

1. Bactéria patogênica 2. Eletroforese 3. Enzima extracelular 4. Enzima proteolítica 5. Fruta cítrica 6. Inibidor de enzima 7. Proteína 8. Uva I. Título

CDD 634.3

"Permitida a cópia total ou parcial deste documento, desde que citada a fonte - O autor" 
Aos meus pais, Geraldo e Maria, pelas valorosas lições de vida e pela eterna confiança em minhas escolhas.

Dedico

Aos meus irmãos José Mario, Maria Luiza e Adriana e aos meus queridíssimos Daniele, Rafael e Bárbara que fazem meus dias mais cheios de vida Ofereço 
As eternas amigas Dri, Fabi, Jully, Carol, Karlinha, Mirian, Simoni, Erica, Vanesca, Isinha, Nany, Vivi, Yasmin e Sandra. Todas nós tomamos diferentes trilhas na vida, mas não importa aonde vamos, aproveitamos um pouco de cada uma delas em toda parte e nos tornamos especiais na vida uma das outras.

Dra. Maria Estela Stenico

A você que, possuindo sabedoria soube transmitir seus confecimentos com amor meu muito obrigada. 


\section{Agradecimentos}

- A Prof. Dra. Siu Mui Tsai pelo orientação e apoio.

- A Dra. Maria Estela Stenico pelo apoio na co-orientação.

- A Profa. Dra. Regina Monteiro e ao Prof. Dr. Luiz Antonio Gallo pela orientação no Exame de Qualificação.

- Especial agradecimento a Adriane Nunes por todas as dicas e carinho com que me ajudou.

- Ao Edenilson pela prontidão em me ajudar.

- Ao Alessandro Riffel e nossas conversas sobre proteases.

- A Dra. Claudia Bellato pelas dicas.

- Aos colegas do Laboratório de Biologia Celular e Molecular; Marina, Leila, Juliana, Camila, Daniele, Karime, Francisco, Wagner, Fabio, Elias, Oton, e Raphael pela ajuda na elaboração deste.

- Aos colegas do Laboratório de Biologia Celular e Molecular que direta ou indiretamente colaboraram para a realização deste. A contribuição de cada um foi fundamental para a conclusão deste trabalho.

- Ao Centro de Energia Nuclear n Agricultura pela oportunidade de realização.

A Deus pela presença constante em minha vida 


\section{LISTA DE FIGURAS}

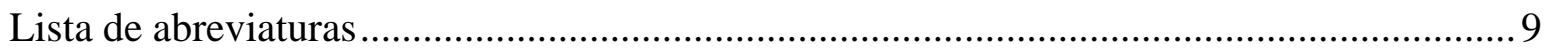

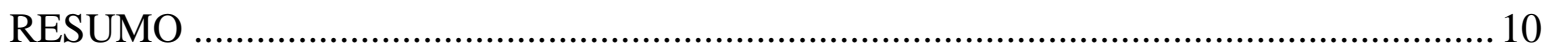

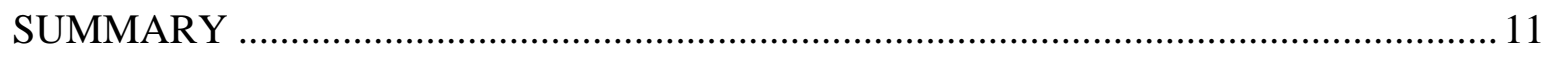

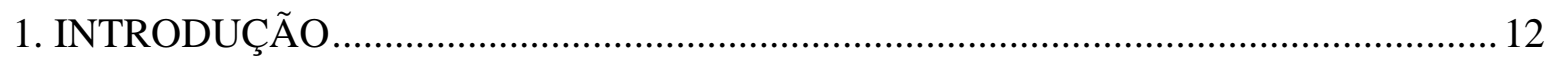

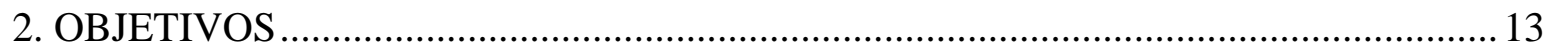

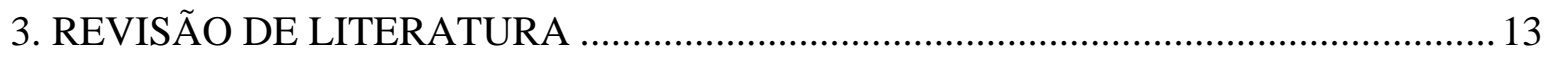

3.1 Xylella fastidiosa ………………………………….......................................... 13

3.2 Sintomas da doença e prováveis mecanismos de patogenicidade/virulência .............. 14

3.3 Enzimas extracelulares .................................................................................... 15

3.4. Mecanismo de secreção de proteínas ......................................................................... 17

3.5.Enzimas proteolíticas/ proteases......................................................................... 18

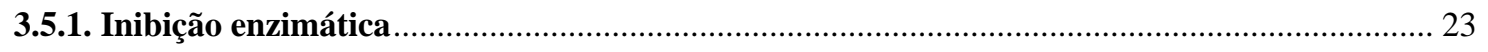

3.6 Extração e Purificação de enzimas......................................................................... 23

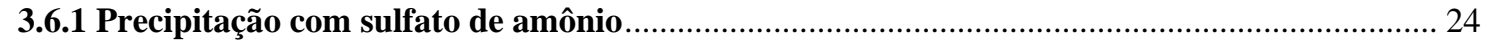

3.7. Eletroforese em poliacrilamida e SDS................................................................... 25

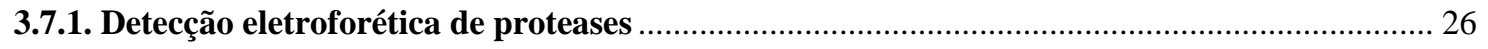

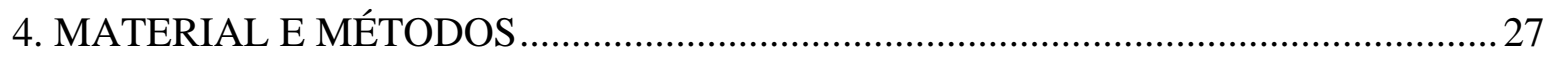

4.1 Isolados de Xylella fastidiosa e condições de cultivo ....................................................2

4.4 Curva de crescimento dos isolados de Xylella fastidiosa ..........................................28

4.5 Determinação de proteínas totais ........................................................................... 29

4.6 Obtenção do sobrenadante …………………………........................................... 30

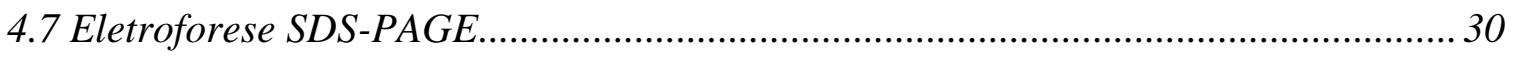

4.8 Efeito da temperatura e do pH na atividade proteolítica ............................................. 30 
4.10 Zonas de hidrólise em substratos....................................................................... 31

4.11 Precipitação com sulfato de amônio........................................................................ 32

4.12 Ensaio para determinação da atividade proteolítica............................................... 32

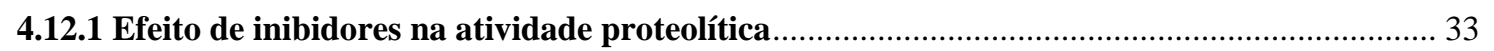

$4.13 \mathrm{Gel}$ de atividade proteolítica.............................................................................. 33

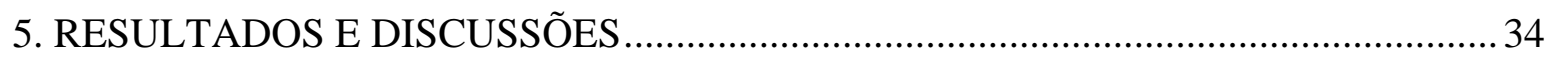

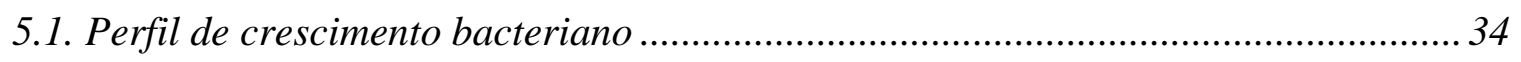

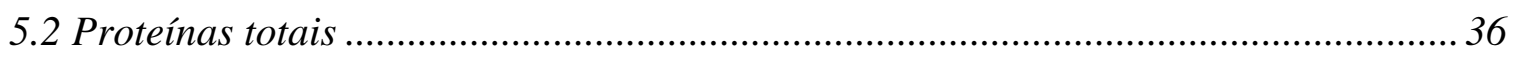

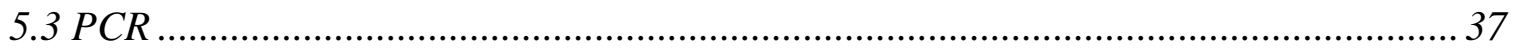

5.4 Perfil de proteínas extracelulares ....................................................................... 38

5.5 pH e temperatura ótimos para atividade de proteases ............................................ 39

5.6 Determinação semi-quantitativa de quitinase e $\beta$-glucanase .................................... 41

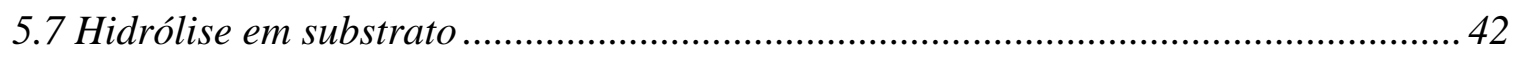

5.8 Quantificação de proteases após precipitação com sulfato de amônio ........................ 45

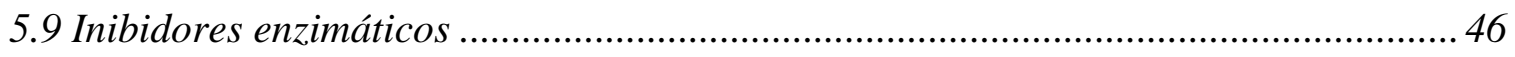

5.10 Efeito de cátions na atividade de proteases extracelulares de X. fastidiosa ............ 49

5.11 Temperatura ótima de proteases.................................................................. 51

5.12 Atividade proteolítica em gel com substrato gelatina........................................... 52

5.13 Efeito dos inibidores na atividade proteolítica .....................................................54

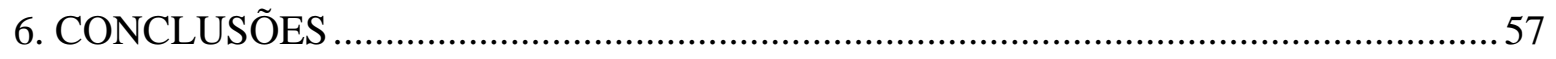

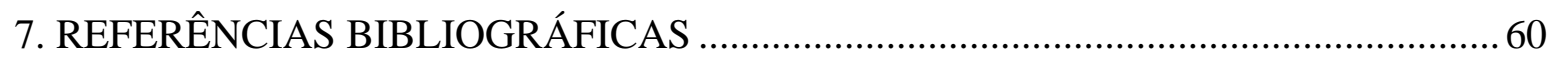


Figura 1. Curva de crescimento de $X$. fastidiosa em meio PW. 35

Figura 2. Proteína total extracelular de isolados de citros e videira ........................36

Figura 3. Produto de PCR analisado em gel de agarose $1,0 \%$................................37

Figura 4. Perfil de proteínas extracelulares de $X$.fastidiosa de citros e videira ..........38

Figura 5. Atividade proteolítica de $X$. fastidiosa em diferentes pHs e temperaturas ..40

Figura 6. Formação de halos indicando a presença de quitinase e $\beta$-1,3-glucanase 42

Figura 7. Formação de halos em substrato gelatina e hemoglobina ..........................43

Figura 8. Atividade relativa de protease após saturação com sulfato de amônio ........45

Figura 9. Efeito de inibidores na atividade de proteases de $X$. fastidiosa de citros ....46

Figura 10. Efeito de inibidores de proteases de $X$. fastidiosa de videira ...................47

Figura 11. Efeito de cátions sobre de proteases de $X$. fastidiosa de citros ...............49

Figura 12. Efeito de cátions de proteases extracelulares de $X$. fastidiosa ..................50

Figura 13. Proteases de $X$. fastidiosa de citros $\left(\mathrm{X}_{0}\right)$ diferentes temperaturas ...........52

Figura 14. Proteases extracelulares dos isolados de $X$. fastidiosa em gel-nativo ..... 53

Figura 15. Perfil de proteases de $X$. fastidiosa de citros com inibidores..................54

Figura 16. Detecção da atividade proteolítica de $X$. fastidiosa de videira...................55

Figura 17. Detecção da atividade proteolítica de $X$. fastidiosa de citros 55 


\section{Lista de abreviaturas}

CVC: Clorose Variegada dos Citros

EDTA: Acido Damino Tetra Acético

SDS: Sodium Dodecyl Sulfate

PAGE: Elatroforese em Gel de Poliacrilamida

ORFs: Open Reading Frames

MM: Massa Molecular

BSA: Soro de Albumina Bovina

TCA: Acido Tricloroacético

3-4 DCI: Dicloroisocoumarim

PCR: Polimerase Chain Reaction 


\section{CARACTERIZAÇÃO DE PROTEASES EXTRACELULARES PRODUZIDAS POR Xylella fastidiosa DE CITROS E VIDEIRA}

Autora: LUCIANA MARIA FEDATTO

Orientadora: Prof. Dra. SIU MUI TSAI

\section{RESUMO}

Xylella fastidiosa é uma bactéria patogênica encontrada em várias plantas. Esta bactéria secreta proteases extracelulares detectadas em gel de eletroforese, sendo a gelatina usada como substrato co-polimerizado. Três principais bandas protéicas foram detectadas com massa molar (MM) de 122, 84 e $65 \mathrm{kDa}$ produzidas pelo isolado de citros $\left(\mathrm{X}_{0}\right)$ e duas bandas de aproximadamente 84 e $65 \mathrm{kDa}$ de isolado de videira (9713). Estas bactérias produziram zonas de hidrólise em meio sólido contendo gelatina, caseína e hemoglobina. Os resultados usando a gelatina como substrato foram os melhores para a atividade das proteases. A atividade enzimática das proteases de $X$. fastidiosa de citros e videira foi completamente inibida por PMSF e parcialmente inibida por EDTA, podendo ser visualizado em gel de eletroforese nativo. A temperatura ótima de atividade protéica foi de $30^{\circ} \mathrm{C}$ e o pH ótimo de 7,0. Além das proteases secretadas por este fitopatógeno, quitinase e $\beta$-1,3-glucanase foram também detectadas no sobrenadante das culturas. Os resultados sugeriram que estas proteases produzidas pela $X$. fastidiosa de citros e videira pertencem ao grupo das serina e metalo proteases. 


\title{
CHARACTERIZATION OF EXTRACELLULAR PROTEASES PRODUCED BY Xylella fastidiosa FROM CITRUS AND GRAPEVINES
}

\author{
Author: LUCIANA MARIA FEDATTO
}

Adviser: Profa. Dra. SIU MUI TSAI

\section{SUMMARY}

Xylella fastidiosa is a pathogenic bacterium found in several plants. These bacteria secrete extracellular proteases into the culture broth as visualized in sodiumdodecyl-sulfate polyacrylamide activity gels containing gelatin as a co-polymerized substrate. Three major protein bands were produced by strain $\mathrm{X}_{0}$ (citrus) with molar masses (MM) of 122, 84 and $65 \mathrm{kDa}$. Grape strain 9713 produced two bands of approximately 84 and $64 \mathrm{kDa}$. These organisms produced zones of hydrolysis in agar plates amended with gelatin, casein and hemoglobin. Gelatin was the best substrate for these proteases. SDS-PAGE activity gel indicated that the protease activities of $X$. fastidiosa from citrus and grape were completely inhibited by PMSF and partially inhibited by EDTA. The optimal temperature for protease activity was $30^{\circ} \mathrm{C}$ with an optimal $\mathrm{pH}$ of 7.0. Among the proteolytic enzymes secreted by the phytopathogen, 
chitinase and $\beta$-1,3-glucanase activities were also detected in cultures of $X$. fastidiosa (citrus). From these results, it is suggested that these proteases produced by strains of $X$. fastidiosa from citrus and grape, belong to the serine- and metallo-protease group. 


\section{INTRODUÇÃO}

A base molecular de doenças epidêmicas e a identificação de fatores que determinam os sintomas, a gravidade e o hospedeiro são assuntos de muito interesse aos fitopatologistas. A ação patogênica de Xylella fastidiosa, causadora de doença em citros, videira, carvalho, amendoeira, ameixeira, pessegueiro, café, amora, olmo, etc. (Wells, 1987; Hopkins,1989), pode ser explicada pela produção de toxinas/oligopeptídeos secretadas por este microrganismo no meio de crescimento, as quais podem ser de natureza protéica (antibióticos ribossomais) ou não-protéica (via não-ribossomal).

Xylella fastidiosa é uma bactéria patogênica que infecta citros e uma grande variedade de outros hospedeiros. No Brasil, estas bactérias causam CVC (clorose variegada dos citros) que afeta a indústria cítrica. Em plantas, elas colonizam e habitam o xilema, tornando difícil o controle deste patógeno (Bellato et al., 2001). Wells et al. (1987) estudaram $X$. fastidiosa de videira, pêssego, periwinkle, erva-de-santiago, amêndoa, ameixa, olmo, sicômoro, carvalho, amora e maple, e identificaram que este patógeno hidrolisou gelatina e que a maioria dos isolados produziram $\beta$-lactamase; porém, não produziram lipase, amilase, coagulase e fosfatase. $X$. fastidiosa de vários hospedeiros produziram proteases extracellulares (Wells et al., 1987). Somente proteases de $X$. fastidiosa que infectam videira e causam Pierce's Disease (PD) foram caracterizadas.

Simpson et al. (2000) demonstraram um elevado grau de homologia entre genes de $X$. fastidiosa e outros patógenos bacterianos como Xanthomonas campestris. Dow e Daniels (2000) sugeriram que o sistema de secreção (tipo II) de $X$. fastidiosa poderia estar envolvido no transporte de enzimas proteolíticas através da parede celular, incluindo endoglucanase, poligalacturonase e proteases. O papel de proteases na patogenicidade depende do sistema patógeno-hospedeiro (Fry et al., 1994), onde as proteases atuam no rompimento das ligações peptídicas e tem um papel em muitas funções fisiológicas (Scopes, 1994; Bertenshaw \& Bond, 2000; Romero et al., 2001). Os grupos catalíticos das proteases são cisteína, serino, aspártico, metalo e grupos não classificados de peptidases e eles são classificados baseados na reação nucleofílica do sítio da enzima (Butler et al., 2001). 
Os inibidores de proteases estão envolvidos em uma variedade de funções do metabolismo celular (Wolf, 1992) e sua importância em desordens patológicas e fisiológicas é bem estudada. $\mathrm{O}$ uso de inibidores específicos para o controle de proteases na interação planta-patógenos foi proposta contra pragas herbívoras (Ryan,1990), fungos (Lorito et al., 1994) e nematóides (Atkinson et al., 1995).

\section{OBJETIVOS}

O objetivo deste trabalho foi estudar algumas características bioquímicas de proteases extracelulares produzidas por $X$. fastidiosa. Baseado no seqüenciamento de $X$. fastidiosa (citros e videira), pôde-se verificar a presença de ORFs (Open Reading Frames) relacionadas com atividade proteolítica. Estas biomoléculas foram caracterizadas com substratos e inibidores específicos.

\section{REVISÃO DE LITERATURA}

\subsection{Xylella fastidiosa}

Xylella fastidiosa é uma bactéria Gram negativa limitada ao xilema das plantas, possui uma ampla faixa de hospedeiros (Tabela 1), incluindo plantas mono e dicotiledôneas, sendo algumas de importância econômica (Weels et al., 1987). No Brasil as maiores perdas são com a CVC.

Plantas infectadas apresentam grande número de células bacterianas capazes de colonizar e bloquear os vasos xilemáticos, cujas paredes são compostas de celulose, hemicelulose e pectina, entre outros componentes e por onde passa a seiva, interferindo no fluxo normal de seiva na planta, apresentando freqüentemente sintomas de murcha, em conseqüência disto, as plantas afetadas perdem cerca de 60\% da capacidade fotossintética (Purcell \& Hopkins, 1996; Rosseti et al., 1997).

A bactéria pode ser transmitida de planta doente para sadia através de insetos vetores da família Cicadelledae subfamília Cicadellinae e Cercopidae que se alimentam da seiva bruta das plantas (Purcell \& Hopkins, 1996). 


\subsection{Sintomas da doença e prováveis mecanismos de patogenicidade/virulência}

Metabólitos secundários, como antibióticos e toxinas microbianas, deveriam ser considerados como produtos naturais de importância ecológica. Muitos metabólitos secundários produzidos por fungos e bactérias desenvolvem atividades multifuncionais, como peptídeo-sintetases, que são enzimas multidomínio e provavelmente estão envolvidas na patogenicidade de $X$. fastidiosa.

Estas bactérias produzem enzimas extracelulares e polissacarídeos capacitando-as a colonizar e parasitar seus hospedeiros (Wilson et al., 1998). Vários tipos de compostos são encontrados em bactérias e agem como toxinas: enzimas, tais como a celulase e pectinase, alguns peptídeos e polipeptídeos, quinonas, aminas, ácido oxálico, antimetabólitos de metionina e hormônios vegetais como giberelinas e auxinas (Drozdowicz, 1991).

No caso do CVC, a planta infectada apresenta folhas de tamanho reduzido e com lesões irreversíveis, desfolhamento, paralisação no crescimento dos ramos, os quais na época da safra apresentam-se excessivamente carregados de frutos pequenos, amarelecidos e com casca extremamente dura. Os sintomas apresentados pelos frutos prejudicam seu valor industrial tornando-os impróprios para o consumo in natura.

Tabela 1. Principais doenças causadas pela bactéria $X$. fastidiosa.

\begin{tabular}{|l|l|l|}
\hline Planta & Sintomas & Referência \\
\hline Citros & $\begin{array}{l}\text { Manchas cloróticas amarelas surgem nas } \\
\text { folhas de plantas afetadas. Frutos são muito } \\
\text { menores que os normais e extremamente } \\
\text { duros. }\end{array}$ & \\
\hline Videira & $\begin{array}{l}\text { Manchas cloróticas nas folhas e dessecação, (1991) } \\
\text { especialmente nas margens. Queda do limbo } \\
\text { foliar, atraso e fraco desenvolvimento da } \\
\text { brotação. Nos cachos podem prejudicar o } \\
\text { desenvolvimento das bagas. }\end{array}$ & \\
\hline
\end{tabular}




\begin{tabular}{|l|l|l|}
\hline Oleander & $\begin{array}{l}\text { Queimadura marginal da folha, morte das } \\
\text { brotações e ramos. }\end{array}$ & \\
\hline Carvalho & $\begin{array}{l}\text { Queimadura marginal da folha, morte das } \\
\text { brotações e ramos em pelo menos algumas } \\
\text { espécies de carvalho. }\end{array}$ & $\begin{array}{l}\text { Sherald \& Kostka } \\
(1992)\end{array}$ \\
\hline Amendoeira & $\begin{array}{l}\text { Escaldadura marginal da folha, morte das } \\
\text { brotações e ramos. }\end{array}$ & Mircetich (1976) \\
\hline Pessegueiro & $\begin{array}{l}\text { Folhas, ramos e frutos anões, folhas mais } \\
\text { escuras e planas. }\end{array}$ & Davis et al. (1981) \\
\hline Café & $\begin{array}{l}\text { Leve diminuição do crescimento, } \\
\text { queimadura marginal das folhas, morte das } \\
\text { folhas e brotações. }\end{array}$ & Beretta et al. (1996) \\
\hline Maple & $\begin{array}{l}\text { Queimadura marginal da folha, morte das } \\
\text { brotações e ramos. }\end{array}$ & Sherald et al. (1987) \\
\hline Amora & $\begin{array}{l}\text { Queimadura marginal da folha, morte das } \\
\text { brotações e ramos. }\end{array}$ & Kostka et al. (1986) \\
\hline Olmo & brotações e ramos. & \\
\hline
\end{tabular}

\subsection{Enzimas extracelulares}

Enzimas extracelulares, tais como as enzimas pectinolíticas e celulases são fatores importantes de virulência para plantas. Estas enzimas degradam polissacarídeos da parede celular, aumentando a habilidade da bactéria em utilizar nutrientes da planta como fonte de energia (Laine et al., 2000).

A ausência de enzimas pectinolitícas funcionais no genoma da $X$. fastidiosa se deve a sua forma de vida, que não requer a invasão e destruição dos tecidos hospedeiros (Keen et al., 2000; Simpson et al., 2000). 
Para patógenos Gram-negativos, a celulase ( $\beta$-1,4-glucanase) tem-se mostrado importante para a virulência de várias espécies, tais como Erwinia carotovora pv. carotovora (Walker et al., 1994) e Ralstonia solanacearum (Roberts et al., 1988), mas atua também em menor intensidade no desenvolvimento de sintomas em Xanthomonas campestris pv. campestris (Gough et al., 1988) e Erwinia chrysanthemi (Boccara et al., 1994).

A $X$. fastidiosa que ataca citros e videira apresenta genes responsáveis pela codificação de uma proteína com estrutura primária semelhante a hemolisina. A $\alpha$ hemolisina é o protótipo da família de proteínas homólogas (principalmente toxinas) secretadas por bactérias Gram-negativas, como por exemplo, Escherichia coli, Proteus, Morganella, Pasteurella, Actinobacillus, Bordetella (Goñi \& Ostolaza, 1998). Estas toxinas possuem um número de características em comum, como a estrutura genética compreendendo de 4 genes (hly no caso de E. coli hemolítica) que são essenciais para a toxicicidade. Este genes codificam 4 proteínas denominadas C, A, B, D. A proteína A é uma citotoxina que é primeiramente sintetizada como uma protoxina inativa, sua maturação ocorre via acilação pós-translacional no resíduo interno de lisina mediado pela proteína C (Nicaud et al., 1985).

Uma via para a absorção direta de ferro se dá através de proteínas específicas como a transferrina, que compreende de lactoferrina ou lactotransferrina, serotransferrina e ovotransferrina (conalbumina). Estas proteínas pertencem a uma família de glicoproteínas monoméricas com massa molar de $\sim 80 \mathrm{kDa}$. Elas se ligam a duas moléculas de íons férricos, com alta afinidade (Aisen, 1998; Sharma et al., 1998). Um número crescente de bactérias patogênicas utiliza a transferrina como via de absorção de ferro (Cornelissen \& Sparling, 1994). Além da transferrina, bactérias podem adquirir ferro de hemoglobina (pela destruição e hidrólise de eritrócitos) ou ferritina, que provavelmente seja a mais comum (Ratledge \& Dover, 2000). Alternativamente a bactéria pode sintetizar um composto com alta afinidade, que captura o ferro da proteína receptora (ferritina ou transferrina). Tais compostos são denominados sideróforos e possuem um papel importante na aquisição de ferro.

São reconhecidos 26 gêneros de bactérias fitopatogênicas, gran positivas e gran negativas, sendo que representantes de muitos desses gêneros (incluindo espécies, 
subespécies e patovares). Dentre aos gêneros: Agrobacterium, Clavibacter, Erwinia, Leifisonia,, Pseudomonas, Ralstonia, Streptomyces, Xanthomonas e Xylella alguns desses patógenos são responsáveis por graves prejuízos econômicos, chegando a construir fator limitante à exploração comercial de diversas culturas de importância econômica. Entretanto, diversas doenças de etiologia bacteriana e importantes economicamente, que ocorrem em outros países, ainda não foram assimiladas no Brasil e sua introdução em áreas indenes constitui uma ameaça real (Wulff, 2002; http://biologico.sp.gov.br/biologico/ 2004)

Estudos de biologia molecular a respeito da patogenicidade da bactéria Xanthomonas c. $p v$. campestris tem sugerido a função de enzimas extracelulares no processo de doença (Dow et al., 1990)

Na ultima década, enzimas extracelulares têm sido intensivamente estudadas como fator de virulência no processo de infecção, e a identificação de numerosas enzimas tem confirmado seu envolvimento no mecanismo molecular de infecção (Xiaow ei et al., 2004).

A função das proteases bacterianas em diferentes doenças pode ser simplesmente nutricional, embora seja possível que haja degradação de proteínas estruturais da parede celular das plantas para permitir o espalhamento das bactérias ou para inibir algumas reações de defesa do hospedeiro (Dow et al., 1990). Protease de Xanthomonas c. pv. campestris degrada proteína da parede celular (Dow et al., 1998).

\subsection{Mecanismo de secreção de proteínas}

As bactérias Gram-positivas são limitadas por uma membrana. Já as Gram-negativas tem citoplasma e periplasma, este localizado entre as duas membranas, interna e externa. Algumas proteínas exportadas das bactérias Gram-negativas permanecem no periplasma, mas outras vão atravessar as duas membranas, sendo secretadas para fora das células. A E. coli em particular não faz bem a secreção para fora da célula, e muitas proteínas que são exportadas em outras espécies Gram-negativas, quando tem o gene inserido em E. coli, são 
transportadas para o espaço periplasmático, mas não além disso (http://acd.ufrj.br/genetica, 2004)

A área de secreção de proteínas vem sendo estudada intensamente, com novos mecanismos descritos e estudados (mecanismos de tipo I, II, III e IV) que estão envolvidos na secreção das proteínas para o espaço extracelular. Conseqüentemente os exportadores ABC estão presentes, baseados principalmente no numero de proteínas secretoras (Omori \& Idei, 2003)

O mecanismo do tipo I utiliza três proteínas: uma proteína de membrana interna, que é uma proteína transportadora $\mathrm{ABC}$, uma outra proteína ligada à membrana interna, mas que se localiza no periplasma, e uma terceira proteína de membrana externa, que em vários casos é a proteína TolC. No caso das proteínas exportadas temos exemplos de toxinas, metaloproteases e lipases. O caso mais conhecido de transporte de proteína utilizando o mecanismo de tipo I é o da secreção da $\alpha$-hemolisina de E.coli patogênica. Neste caso a proteína de membrana externa envolvida é a TolC. A proteína TolC forma um canal contínuo com a proteína periplasmática e a proteína ABC, forma um caminho direto para a exportação da hemolisina (http://acd.ufrj.br/genetica, 2004).

A translocação de proteínas para o espaço extracelular é essencial para a invasão, colonização e sobrevivência de bactéria patogênica gran-negativa dentro do organismo do hospedeiro (Oori \& Idei, 2003).

\subsection{Enzimas proteolíticas/ proteases}

Com exceção de um pequeno grupo de moléculas de RNA com propriedades catalíticas, todas as enzimas são proteínas. A sua atividade catalítica depende da integridade da sua conformação protéica nativa. A atividade catalítica geralmente se perde caso uma enzima seja desnaturada ou dissociada em subunidades. A atividade catalítica é sempre destruída quando uma enzima é rompida em seus aminoácidos componentes. Assim, as estruturas protéicas primárias, secundária, terciária e quaternária das enzimas são essenciais para a função de atividade catalítica.

Para serem ativas, algumas enzimas não requerem nenhum outro grupo químico além dos seus resíduos de aminoácidos. Outras requerem componentes químicos adicionais 
chamados de cofatores. Um cofator pode ser um ou mais íons inorgânicos, tais como $\mathrm{Fe}^{2+}$, $\mathrm{Mg}^{2+}, \mathrm{Mn}^{2+}$ ou $\mathrm{Zn}^{2+}$, ou uma molécula orgânica complexa chamada de coenzima. Algumas enzimas requerem ambos, uma coenzima e um ou mais íons metálicos, para exibirem sua atividade. Uma coenzima que está covalentemente ligada à parte protéica da enzima é chamada de grupo prostético. Uma enzima completa, cataliticamente ativa, unida à sua coenzima e/ou íons metálicos, é chamada de holoenzima.

A ligação peptídica é a ligação covalente mais importante que une os aminoácidos para formar peptídeos e proteínas. A hidrólise das ligações peptídicas é, portanto, um passo necessário na determinação da composição em aminoácidos das proteínas. As ligações peptídicas podem também ser hidrolisadas por determinadas enzimas chamadas proteases. Elas são enzimas proteolíticas (quebram as ligações peptídicas das proteínas) e são encontradas em todas as células e tecidos, onde elas degradam proteínas que se tornaram desnecessárias ou danificadas, além de ajudarem na digestão dos alimentos protéicos (Lehninger, 1995).

As enzimas proteolíticas, proteases ou proteinases pertencem ao grupo das hidrolases as quais têm em comum o envolvimento da água na formação do produto. As proteinases catalisam a reação de hidrólise das ligações peptídicas das proteínas, ocorrendo a transferência de componentes do substrato para a água (Whitaker, 1994).

Enzimas proteolíticas ou proteases catalisam a quebra das ligações peptídicas em proteínas. São enzimas da classe 3, as hidrolases, e subclasse 3.4, as peptídeo-hidrolases ou peptidases. Estas enzimas constituem uma grande família (EC 3.4), dividida em endopeptidases ou proteinases (EC 3.4. 21-99) e exopeptidases (EC 3.4.11-19), de acordo com a posição da ligação peptídica a ser clivada na cadeia peptídica (Beynom \& Bond, 1989). Estas endopeptidases podem ser ainda subdivididas de acordo com o grupo reativo no sítio ativo envolvido com a catálise em serina- (EC 3.4.21), cisteína- (EC 3.4.22), aspártico-proteinases ou endopeptidases (EC 3.4.23) e metaloproteinases ou metaloendopeptidases (EC 3.4.24). Serina peptidases possuem um resíduo de serina em seu sitio ativo, enquanto as aspártico-peptidases têm duas unidades de ácido aspártico no seu centro catalítico. Cisteína-proteases apresentam um aminoácido cisteína e as metaloproteases usam um íon metal no seu mecanismo catalítico. As enzimas cujo mecanismo de 
ação não está completamente elucidado são classificadas no subgrupo EC. 3.4.99. (Neurath, 1989).

A capacidade de uma enzima catalisar uma reação específica é talvez sua propriedade mais significativa. A atividade catalítica de uma enzima proporciona um meio sensível e específico para sua própria mensuração. Sob condições apropriadas, a velocidade de uma reação enzimática depende das concentrações de enzima e de substrato. Os resultados são expressos em unidades (U) enzimáticas: 1 U é a quantidade de enzima que catalisa a formação de $1 \mathrm{mmol}$ de produto por minuto sob condições definidas.

A reação enzimática pode ser expressa pela seguinte equação:

$\mathrm{E}+\mathrm{S}<==>[\mathrm{ES}]==>\mathrm{E}+\mathrm{P}$

Onde: $\mathrm{E}=$ enzima, $\mathrm{S}=$ substrato e $\mathrm{P}=$ produto

O principal papel das enzimas proteolíticas é nutricional, onde estas hidrolizam grandes cadeias polipeptiídicas em pequenas moléculas que a célula possa absorver, sendo sabido que estão envolvidas em outros processos biológicos, como formação e germinação de esporos e ciclo celular, sendo estas enzimas geralmente sintetizadas junto à membrana celular, numa forma precursora e depois liberadas na forma final ativa por proteólise. A extensão peptídica que é removida nesse processo parece ser de natureza hidrofóbica o que facilita a passagem da enzima, através da membrana (Sogart, 1983).

As enzimas, entretanto, apresentam uma faixa de temperatura e $\mathrm{pH}$ ótimos, fora destes padrões podem sofrer desnaturação.

Proteases podem contribuir para a patogenicidade causando danos diretos nos tecidos ou aumentando a capacidade de invasão (Sakai, 1985 a e b). Sendo também a maior ferramenta em análise de seqüência de proteínas e em identificação e isolamento de domínios de complexo multifuncional (Michaud, 1998).

Estudos vêm sendo desenvolvidos para caracterizar proteases de bactérias fitopatogênicas a fim de determinar sua função no desenvolvimento de doenças Fuji \& Vematsu (1975) estudaram proteases de Xanthomonas oryzae; Sun (1991) Xanthomonas campestris $p v$. Zinniae. O gênero Erwinia foi outro fitopatógeno avaliado quanto sua capacidade de produzir proteases, por Sinhá \& Prasad (1983) Erwinia carotovora 
chrysanthemi e Erwinia chrysanthemi (Barras et al., 1986; Wandersman et al.,1986); Erwinia c. subsp. carotovora (Kyostio et al., 1991) e Heilbronn (1995) que caracterizou uma metalo protease. Segundo Zhang (1999) Erwinia amylorova também produziu uma metalo protease.

Segundo Fry et al. (1994), X. fastidiosa PD (Pierce's Disease) produziu duas proteases P1 e P2 de 50 e $54 \mathrm{kDa}$, respectivamente, as quais foram ativas em gelatina e caseína.

Deve-se considerar, entretanto, que a caracterização da enzima quanto ao substrato degradado requer uma relação com a disponibilidade e presença do substrato na planta (Wulff, 2002).

São vários os procedimentos analíticos usados para o ensaio de proteases, refletindo a grande diversidade de natureza nesse grupo de enzimas (Braga, 1992).

A produção de enzimas depende da temperatura, mas nem sempre a temperatura ótima da síntese de uma determinada enzima coincide com a temperatura ótima de crescimento do microrganismo. É preciso considerar ainda que a temperatura ótima da atividade de uma enzima para um substrato pode diferir da temperatura ótima de crescimento e daquela da síntese enzimática.

As enzimas contêm grupos ionizáveis e, portanto, o pH do meio de cultura afeta sua estrutura e função. O crescimento de células microbianas também é influenciado pelo pH, uma vez que a síntese dos constituintes básicos do desenvolvimento celular depende de íons. Assim como para a temperatura, o pH ótimo de crescimento celular e de produção podem diferir (Said \& Pietro, 2002).

Proteases são encontradas em vários microrganismos, como vírus, bactérias, protozoários, leveduras e fungos. Podendo ser extracelulares e intracelulares, ligadas ou não a membrana. A impossibilidade das proteases de plantas e animais atenderem à demanda mundial de enzimas tem levado a um interesse cada vez maior pelas proteases de origem microbiana. Microrganismos representam uma excelente fonte de proteases devido a sua grande diversidade bioquímica, permitem que o rendimento de enzimas por fermentação possa ser incrementado através de manipulação genética e melhoramento das condições de cultivo. Proteínas são degradadas por microrganismos, que utilizam os produtos de degradação como nutrientes para o seu crescimento (Neurath, 1989; Said \& Pietro, 2002). 
A degradação é iniciada por proteinases (endopeptidases) secretadas pelos microrganismos, seguida de hidrólise posterior por peptidases (exopeptidases) em um sítio extra- ou intracelular. ( http://acd.ufrj.br/proteases, 2004)

Proteases microbianas contam aproximadamente por $40 \%$ da venda total mundial de enzimas. Proteases de origem microbiana são preferidas às enzimas de plantas e animais, uma vez que elas possuem a maioria das características desejadas para aplicação em biotecnologia, e seu custo de produção, de maneira geral, é menor do que aqueles das enzimas de origem vegetal ou animal. Apesar destas vantagens, sabe-se que um único microrganismo pode produzir várias enzimas e, assim, a presença de enzimas contaminantes pode produzir reações indesejáveis, requerendo métodos de purificação ou de inativação diferencial para separá-las (Said \& Pietro, 2002).

O conhecimento das características fisico-químicas das enzimas produzidas por microrganismos é de fundamental importância para os estudos de aplicações industriais e biotecnológicas.

Em humanos, enzimas proteolíticas são importantes não somente na hidrólise de dieta protéica, estando também envolvidas em processos biológicos essenciais, como a coagulação sangüínea, morte celular e diferenciação de tecidos. Várias etapas proteolíticas importantes ocorrem no mecanismo invasivo de tumores, assim como no ciclo de infecção de um grande número de vírus e microrganismos patogênicos, dentre eles herpes (Aoki et al., 1995), doença de Alzheimer (Eriksson et al.,1995) e doenças infecciosas como a AIDS (Kaplan et al., 1993). Estes fatos tornam as proteases um alvo quimioterápico valioso para o desenvolvimento de novos compostos farmacêuticos.

O isolamento de proteínas nativas intactas de tecido biológico requer inativação de interferência de proteases por inibidor específico. Proteases constituem um dos mais importantes grupos de enzimas industriais, sendo responsáveis por $60 \%$ da venda internacional de enzimas, tendo aplicação em diversas indústrias, dentre elas, de detergentes, alimentação e farmacêutica (Said \& Pietro, 2002). 


\subsubsection{Inibição enzimática}

Os inibidores enzimáticos são compostos que podem diminuir a atividade de uma enzima. A inibição enzimática pode ser reversível ou irreversível; existem dois tipos de inibição enzimática reversível.

\section{Inibição Reversível Competitiva}

Quando o inibidor se liga reversivelmente ao mesmo sítio de ligação do substrato o efeito é revertido aumentando-se a concentração de substrato. Este tipo de inibição depende das concentrações de substrato e de inibidor.

\section{Não competitiva}

Quando o inibidor liga-se reversivelmente à enzima em um sítio próprio de ligação, podendo estar ligado à mesma ao mesmo tempo que o substrato; este tipo de inibição depende apenas da concentração do inibidor. Na inibição irreversível, há modificação covalente e definitiva no sítio de ligação ou no sítio catalítico da enzima.

Inibidores de proteases estão presentes em tecidos vegetais e animais. O interesse em estudar suas funções fisiológicas se dá devido a sua importância na regulação de diferentes processos nas quais as proteases estão envolvidas, desde a lise de proteínas intracelulares, transcrição, ciclo celular, invasão celular, apoptose, entre outras (Salvesen \& Nagase, 1989; Fumagalli et al., 1996; Kato, 1999).

\subsection{Extração e Purificação de enzimas}

Vários métodos têm sido descritos para a purificação de enzimas. Eles envolvem precipitação por sulfato de amônio, exclusão por tamanho, cromatografia de troca iônica (Lascu et al., 1986; Chavez \& Flurkey, 1984), por afinidade utilizando metais como ligantes (Silva \& Franco, 2000), sistema de duas fases aquosas (Silva et al., 1997), entre outros métodos. 
Manter a concentração protéica alta durante as etapas de extração e purificação é um bom ponto de partida. Isto ajuda a manter complexos protéicos, além de fornecer um ambiente estabilizador para a proteína de interesse e evitar a rápida perda da atividade catalítica. Soluções enzimáticas muito diluídas levam a uma perda de atividade. Condições redutoras, pH próximo da neutralidade e moderada força iônica são outras condições importantes a serem mantidas (Scopes, 1987).

O objetivo da purificação de enzimas é o isolamento da enzima específica a partir de um extrato bruto de células contendo muitos outros componentes, de forma a se obter o máximo de atividade específica (unidade enzimática por mg de proteína) com a melhor recuperação possível da atividade inicial.

\subsubsection{Precipitação com sulfato de amônio}

A precipitação faz com que proteínas sejam separadas pela conversão de proteínas solúveis para um estado insolúvel. O que se busca com a precipitação é a remoção de contaminantes não protéicos e a remoção de proteínas que não sejam a(s) de interesse. Também por reduzir o volume acaba concentrando mais as proteínas.

O sulfato de amônio é o precipitante mais usado em salting out de proteínas, devido a algumas vantagens:

- A precipitação da maioria das proteínas ocorre em uma molaridade suficientemente alta;

- Não promove o aquecimento da solução;

- A solução saturada $\left(4,04 \mathrm{M}\right.$ a $\left.20^{\circ} \mathrm{C}\right)$ apresenta uma densidade $\left(1,235\right.$ g. $\left.\mathrm{cm}^{3}\right)$ que não interfere na sedimentação da maioria das proteínas durante a centrifugação;

- Soluções concentradas não permitem o crescimento de bactérias;

- A maioria das proteínas ficam protegidas contra a desnaturação quando em solução (Englard \& Seifter, 1990).

A precipitação fracionada com sulfato de amônio ao mesmo tempo em que concentra as proteínas, separa-as grosseiramente pela sua massa molecular (Scopes, 1982). 


\subsection{Eletroforese em poliacrilamida e SDS}

A técnica de SDS-PAGE combina propriedades desnaturantes do detergente SDS (dodecil sulfato de sódio) com o poder de separação de moléculas da eletroforese em gel de poliacrilamida (PAGE). A eletroforese consiste na migração de moléculas ionizadas, de acordo com suas cargas elétricas e massas molares em um campo elétrico (Stryer, 1992; Silva et al, 1992; Hames,1998).

Moléculas com carga negativa migram para o pólo positivo (ânodo) e moléculas com carga positiva migram para o pólo negativo (cátodo). A velocidade de migração depende da intensidade do campo elétrico, da carga total da molécula e do coeficiente de atrito (poros do gel). O gel de eletroforese separa proteínas por carga e tamanho, possuindo poros de tamanhos variados de acordo com a composição do gel requerida para a proteína que se deseja separar (Hames, 1998).

A carga líquida das moléculas de proteínas é função somatória dos aminoácidos que as constituem. Em pH neutro, os aminoácidos lisina (Lys), arginina (Arg) e histidina (His) contribuem com carga positiva e os aminoácidos glutamina (Glu) e asparagina (Asp) com carga negativa (Lehninger, 1995).

O SDS é um detergente aniônico que se liga às proteínas por interações hidrobóbicas, rompendo a maioria das ligações não covalentes, a uma razão de 1,4g de SDS/g de proteína, aproximadamente uma molécula de SDS para cada dois resíduos de aminoácidos. (Dunn, 1993). A desnaturação das proteínas pelo detergente SDS são basicamente explicados da seguinte forma: proteínas e peptídeos são formados por aminoácidos ligados covalentemente por ligações peptídicas regularmente arranjadas, sendo a massa molar diretamente proporcional ao numero de aminoácidos. Svasti \& Panjan (1977).

As proteínas são desnaturadas por aquecimento, na presença de agente redutor de $\beta$ mercaptoetanol ou DTT (ditiotreitol), e SDS, estes reduzem as ligações dissulfeto tornando a cadeia de polipeptídeo linear a qual adquire a carga negativa do SDS. (Alfenas \&Brune,1998). As proteínas são substancia anfóteras capazes de adquirir carga positiva ou negativa em função do pH. É, portanto, boa pratica manter constante o pH do meio durante a eletroforese pelo uso de soluções-tampão (Alfenas et al., 1991) 
A técnica de SDS-PAGE pode ser realizada por sistema contínuo ou descontínuo. No primeiro, é utilizado gel de poliacrilamida em apenas uma concentração e pH. No sistema descontínuo desenvolvido por Laemmli (1970), são utilizados dois géis com concentrações e pHs diferentes: sendo, um gel de corrida e outro gel de empilhamento, este tem pH e concentração menores, permitindo uma melhor organização no empilhamento e na corrida das proteínas de acordo com suas massa moleculares, impedindo desta forma que polipeptideos interfiram na migração de um de menor peso (Sambrook \& Russell, 2001).

Desse modo, a separação das proteínas é feita exclusivamente por massa molar, Isto determinará que somente a MM da proteína irá influenciar a migração eletroforética neste tipo de gel.

\subsubsection{Detecção eletroforética de proteases}

Segundo Michaud (1998), existem vários procedimentos para deteç̧ão de enzimas proteolíticas em gel de eletroforese. Na maioria dos casos, proteínas do extrato contendo proteases são primeiramente verificadas em gel sob condições nativa ou fracamente desnaturadas e então ocorre a hidrólise da proteína ou substrato sintético em condições controladas.

A técnica de análise do gel de eletroforese para estudar enzimas proteolíticas pode ser dividida em dois grupos: aqueles os quais as proteases são detectadas “in situ” após eletroforese e aqueles os quais são detectadas em um gel contendo o substrato ou uma membrana de nitrocelulose. A análise do gel pode ser de acordo com o tipo de substrato usado (natural ou sintético), o qual é determinado pela quantidade de informação disponível sobre a amostra e o nível de especificidade necessária durante a análise enzimática, dentre as proteínas (naturais), mais usadas estão a gelatina, primeiramente descrita por Heussen \& Dowdle (1980), caseína, albumina de soro bovino e hemolisina.

Na maioria dos estudos proteases são caracterizadas em ensaios com $\beta$-caseína, entretanto, o envolvimento na patogênese não é comprovado, sendo provavelmente importantes para a utilização de produtos protéicos liberados da célula vegetal após sua lise (Wulff, 2002). 
O gel de eletroforese oferece várias vantagens na análise de proteases, incluindo a possibilidade de detectar atividade de proteases na forma de complexo, extrato bruto, sem a necessidade de passar por purificações preliminares, estimando suas MM e seus inibidores, para analisar funções características das proteases detectadas e estudo das interações protease-inibidor.

Após a separação física no gel, as proteínas são detectadas através de procedimentos de coloração apropriados, formando padrões de bandas. Até mesmo 0,1 mg de proteína apresenta uma faixa distinta quando corada com azul de Coomassie. Proteínas com massas diferindo em cerca de 2\% (diferença de cerca de 10 aminoácidos) podem geralmente ser distinguidas (Westermeier et al., 1993).

\section{MATERIAL E MÉTODOS}

Este trabalho foi desenvolvido no Laboratório de Biologia Celular e Molecular do Centro de Energia Nuclear na Agricultura - CENA/USP, Piracicaba-SP.

\subsection{Isolados de Xylella fastidiosa e condições de cultivo}

Para fins comparativos, foram utilizados cincos isolados de $X$. fastidiosa, sendo três deles de citros e dois de videira: isolado 9a5c de Citrus sinensis (L.) o qual teve seu genoma completamente sequenciado por Simpson et al. (2000), isolado de citros SR3; SR28 da espécie hospedeira Citrus sinensis, da região de Santa Rita do Passa Quatro-SP, os quais fazem parte da coleção do Laboratório de Biologia Celular e Molecular, CENA USP, sendo que o SR3 foi obtido de planta sintomática (CVC) e o SR28 obtido de planta assintomática. O isolado IAPAR 9713 e o isolado Temécula de Vitis vinifera foram obtidos da coleção bacteriológica do Instituto Agronômico do Paraná (Londrina, PR). Todos os isolados foram mantidos em glicerol $(50 \%)$ a $-80^{\circ} \mathrm{C}$.

Os isolados foram cultivados em meio PWG (Hills e Purcell, 1995), modificado em PW (DAVIS et al., 1981). O meio de cultivo consistiu de: 0,4\% Fitona peptona (BBL 4311906); 0,1\% Tripticase peptona (BBL 4311921); 0,001\% Cloreto de hemina; 0,002\% 
Vermelho de fenol; 0,12\% $\mathrm{K}_{2} \mathrm{HPO}_{4} ; 0,10 \% \mathrm{KH}_{2} \mathrm{PO}_{4} ; 0,04 \% \mathrm{MgSO}_{4}$. $7 \mathrm{H}_{2} \mathrm{O} ; 1,2 \%$ ágarágar; 0,4\% L-glutamina. As culturas foram mantidas a $28^{\circ} \mathrm{C}$ sob ausência de luz.

\subsection{Isolamento de DNA genômico:}

Para a extração de DNA genômico, obteve-se células dos isolados de $X$. fastidiosa cultivadas em meio PW. A extração se deu através do kit Ultraclean MO BIO Laboratories, número de catálogo 12800-50 (www.mobio.com, 2004).

\subsection{Amplificação do gene 16S rRNA específico para Xylella fastidiosa}

O gene 16S rRNA foi amplificado por PCR com primers específicos desenvolvidos por Rodrigues et al (2003). Amplificações do gene 16S rRNA por PCR foram feitas em volume de $50 \mathrm{~mL}$ contendo 5 pmol de oligonucleotídeos iniciadores, 200 mM de cada dNTP, 1 X Taq tampão, 1.5 Taq DNA polimerase (Invitrogen Inc., São Paulo), e 50 hg de DNA. O PCR foi iniciado com 3 min de desnaturação a $94^{\circ} \mathrm{C}$; seguido de 30 ciclos com desnaturação a $94^{\circ} \mathrm{C}$ por $1 \mathrm{~min}$, anelamento a $58^{\circ} \mathrm{C}$ por 30 s, extensão a $72^{\circ} \mathrm{C}$ por 30 s, e extensão final por 5 min $5 \mathrm{~mL}$ do produto de PCR foi analisado em gel de agarose $1.0 \%$.

\subsection{Curva de crescimento dos isolados de Xylella fastidiosa}

Para obtenção do perfil de crescimento, células das culturas (placa de petri) foram recolhidas assepticamente com alça de platina e inoculadas em $20 \mathrm{ml}$ de meio PW líquido sendo esta considerada a cultura inicial (pré-inóculo), incubadas sob agitação de 140 rpm, $28^{\circ} \mathrm{C}$ e ausência de iluminação, durante 4 dias. Alíquotas de $4 \mathrm{~mL}$ retiradas do pré-inóculo foram transferidas para frascos Erlenmeyers de $500 \mathrm{~mL}$ contendo $200 \mathrm{~mL}$ de meio PW, sendo as culturas mantidas nas mesmas condições da cultura inicial, realizado em triplicata para todos os isolados. 
Amostras contendo $1 \mathrm{~mL}$ foram retiradas diariamente de cada erlenmeyer. O crescimento bacteriano foi acompanhado através da densidade ótica sob absorbância de 600 nm em espectrofotômetro Perkin Elmer (UV/VIS Lambda BIO).

\subsection{Determinação de proteínas totais}

A concentração de proteínas totais foi determinada de acordo com Bradford (1976). Este método está fundamentado na reação colorimétrica entre os grupos aromáticos da proteína e o corante azul de Coomassie em meio ácido.

As alíquotas de $1 \mathrm{~mL}$ das culturas, que foram utilizadas para determinação da curva de crescimento, descrito anteriormente, foram então centrifugadas durante 6 min., $25^{\circ} \mathrm{C}$ e $5000 \times g$, sendo que $100 \mu \mathrm{L}$ do sobrenadante foi adicionado a $1 \mathrm{~mL}$ do reagente (descrito abaixo). O branco foi preparado com $100 \mu \mathrm{L}$ de meio PW em substituição ao sobrenadante. Os tubos foram agitados vagarosamente, aguardado 10 min., mas não mais que uma hora, e a leitura foi realizada em espectrofotômetro a $595 \mathrm{~nm}$.

A técnica está descrita a seguir:

\section{Preparo do reagente:}

Dissolver 100 mg de azul de Coomassie G-250 em 50 ml de etanol 95\%.

Acrescentar $100 \mathrm{ml}$ de ácido fosfórico 85\% (m/v).

Diluir esta solução para 1 litro.

Concentração final de cada reagente: Blue Coomassie = 0,01\% (m/v), etanol = 4,7\% (m/v), ác. fosfórico $=8,5 \%(\mathrm{~m} / \mathrm{v})$.

\section{Curva padrão}

Soluções contendo de 1 a $10 \mu$ g de proteína albumina de soro bovina (BSA), volume final de $100 \mu \mathrm{l}$ foram adicionadas a $1 \mathrm{ml}$ do reagente (descrito anteriormente). Volume final $=1,1 \mathrm{ml}$. 
Sendo o branco preparado com $100 \mu \mathrm{l}$ de água e $1 \mathrm{ml}$ do reagente. Os tubos foram agitados vagarosamente, aguardado 10 min., mas não mais que uma hora, e a leitura foi realizada em espectrofotômetro à 595 nm (Figura 1 - ANEXO).

\subsection{Obtenção do sobrenadante}

Culturas dos isolados da bactéria $X$. fastidiosa foram centrifugadas por $30 \mathrm{~min}, 25^{\circ} \mathrm{C}$ a $10.000 \times g$, com a finalidade de obter o sobrenadante livre de células para então realizar os experimentos.

\subsection{Eletroforese SDS-PAGE}

Eletroforese em gel de poliacrilamida em condições desnaturantes (SDS-PAGE) foi realizada em um gel de separação homogêneo 12\% (Laemmli, 1970, Andrews, 1986). A corrida eletroforética ocorreu a $60 \mathrm{~V}$ até as proteínas atingirem o gel de separação, quando a voltagem foi elevada para $100 \mathrm{~V}$ no equipamento Mini-Protean da Bio-Rad de acordo com as instruções do fornecedor. A coloração dos géis foi realizada com nitrato de prata. O padrão de (MM de proteínas utilizado foi de 225, 150, 100, 75, 50, 35, 25, 15 e 10 kDa, estando as proteínas presentes na concentração de $0,1 \mu \mathrm{g} \mu \mathrm{L}^{-1}$, exceto a de $50 \mathrm{kDa}$ presente a $0,3 \mu g \mu \mathrm{L}^{-1}$.

\subsection{Efeito da temperatura e do $\mathrm{pH}$ na atividade proteolítica}

O efeito do $\mathrm{pH}$ na atividade proteolítica de $X$. fastidiosa foi examinado nas faixas de pH de 5,0; 6,0; 7,0; 8,0; 9,0 (tampões 50 mM: citrato de sódio pH 5,0; fosfato de sódio pH 6,0, e 7,0; borato $\mathrm{pH}$ 8,0 e 9,0). A temperatura ótima de atividade foi determinada com mistura de reação tamponada com o ótimo de $\mathrm{pH}$ já determinado. As temperaturas estudadas foram entre $10,20,30,40$ e $50^{\circ} \mathrm{C}$. 


\subsection{Detecção semi-quantitativa de enzimas degradadoras de polissacarídeos de $X$. fastidiosa}

Foi preparado tampões citrato de sódio (0,1 M) pH 5,0, fosfato de sódio pH 6,0 e 7,5 e agar (4\%). Sendo adicionado a estes $2 \mathrm{mg} \mathrm{mL}^{-1}$ de CM-Chitin-RBV ou CM-CurdlanRBB (polissacarídeos). Estas solução foram autoclavadas e adicionadas em placas de Petri. Pequenos pocinhos foram feitos nas placas de agar e $100 \mu \mathrm{L}$ de sobrenadante foram adicionados a cada 12 horas. As placas de Petri foram armazenadas a $30^{\circ} \mathrm{C}$ por 3 dias.

CM-Chitin-RBV permanece solúvel e estável em tampão Na-acetato 50 mM, pH 5. Após determinado tempo de incubação, a reação enzimática é bloqueada com a adição de ácido hidroclorídrico ( $1 \mathrm{~N}, 20 \%$ v/v volume final). O substrato não degradado, de massa molar elevada é precipitado na mistura de reação a $\mathrm{pH}$ menor que 3 , enquanto que os produtos de degradação do corante permanecem na solução. CM-Chitin-RBV é usado para análises colorimétricas de atividade de quitinase e CM-Curdlan-RBB para analise de $\beta$-1,3glucanase. Usando-se tampão e ágar contendo um desses polissacarídeos e adicionando-se a amostra, é possível obter um método sensível com formação de halos ao redor das amostras

Análise de atividade quitinolítica incluem métodos viscosimétricos usando derivados solúveis de quitina (Ohtakara, 1988), quitina coloidal, ou métodos radioquímicos baseados na formação de quito-oligassacarídeos solúveis de quitina-H3 regenerada (Cabib, 1988). Este último método é mais sensível, porém fica restrito a laboratórios que possuam equipamentos especiais.

\subsection{Zonas de hidrólise em substratos}

Para se verificar o melhor substrato para as proteases foi feito um tampão sólido contendo $1 \%$ de gelatina, caseína ou hemoglobina e foram feitos pocinhos nas placas de Petri. Em cada pocinho foi adicionado $100 \mu \mathrm{L}$ do sobrenadante (a cada 12 horas) e incubados. Após a incubação a $30^{\circ} \mathrm{C}$ por 3 dias, o diâmetro das zonas de hidrólise foi medido, sendo realizado em triplicata. 


\subsection{Precipitação com sulfato de amônio}

O sobrenadante das culturas (correspondente ao $3^{\underline{0}}$ dia de crescimento para $X$. fastidiosa de videira e $6^{-}$dia para citros) foi fracionado em solução saturada de sulfato de amônio 65\% precipitando-se proteínas por centrifugação a $10.000 \times g$ por 20 min. a $4^{\circ} \mathrm{C}$, reservado o precipitado, em seguida, procedendo-se a precipitação do sobrenadante a 90\%. Os precipitados do 65\% e 90\% foram ressuspendidos em tampão fosfato de potássio 50 $\mathrm{mM} \mathrm{pH}$ 7,0. A fim de retirar o excesso de sulfato de amônio o material foi dialisado em membrana de celulose (MM $14.000 \mathrm{KDa}$ ) por 24 horas a $8^{\circ} \mathrm{C}$ com tampão fosfato de potássio $5 \mathrm{mM}$, trocando-se o tampão por duas vezes. A fração dialisada foi centrifugada a $10.000 \times g$ por 10 min. e armazenada a $-80^{\circ} \mathrm{C}$ antes do uso (Tabela $1-\mathrm{ANEXO}$ ).

\subsection{Ensaio para determinação da atividade proteolítica}

Para determinação da atividade enzimática foi utilizada metodologia citada por Fry et al. (1994) de Tseng \& Mount (1974), sendo que todas as soluções foram equilibradas a $28^{\circ} \mathrm{C}$. Foi adicionado $1 \mathrm{~mL}$ do substrato gelatina $1.0 \%$ (m/v) (tampão Tris- $\mathrm{HCl} 0.05 \mathrm{M}$ (pH 6.0) contendo $0.01 \% \mathrm{CaCl}_{2}$ ) a $1 \mathrm{~mL}$ do sobrenadante de $X$. fastidiosa. A solução foi agitada suavemente para evitar a formação de espuma, e a solução foi incubada a $30^{\circ} \mathrm{C}$ por 30 min. A reação foi paralisada pela adição de $3 \mathrm{~mL}$ de ácido tricloroacético (TCA) 15\% (m/v) para os ensaios. O branco foi preparado combinando TCA com a solução a ser testada e então adicionado o substrato. A seguir foram centrifugados a $5.000 \times g$ por 15 min. Todos os ensaios ficaram em repouso por 30 min. e foram filtrados em papel Whatman $\mathrm{n}^{0} 3$.

A leitura de absorbância do filtrado com relação ao branco foi realizada em cubeta de quartzo com via óptica de $4 \mathrm{~mm}$ a $280 \mathrm{~nm}$, diluindo-se os filtrados (inclusive o branco) quando necessário. A maior absorbância do filtrado em relação ao branco é devido à presença de aminoácidos naquela solução. Uma unidade de atividade enzimática foi definida como a quantidade de enzima requerida para causar um aumento de 0,01 U na absorbância a $280 \mathrm{~nm}$ sob as condições do ensaio. 


\subsubsection{Efeito de inibidores na atividade proteolítica}

Ensaios para avaliar a ação dos inibidores foram realizados com 1,0 mL do sobrenadante de $X$. fastidiosa e inibidores na concentração final de 0,1, 1 e $10 \mathrm{mM}$ : Leucina e EDTA (inibidores de metalo-protease); Aprotinin (inibidor de serina e cisteínaprotease); PMSF e 3-4 DCI (inibidores de serina-protease); $\beta$-Mercaptoethanol (inibidor de cisteína-protease) e Pepstatin A (inibidor de aspártico-protease). O efeito dos seguintes cations foram também verificados: $\mathrm{MgCl}_{2}, \mathrm{CaCl}_{2}, \mathrm{ZnCl}_{2}, \mathrm{CuCl}_{2}, \mathrm{MnCl}_{2}, \mathrm{KCl}_{2}, \mathrm{NaCl}_{2}$ e $\mathrm{FeCl}_{2}$. Uma mistura de concentração final de 1 e $10 \mathrm{mM}$ de cátions divalentes, substrato e enzima foram utilizados.

A solução foi agitada suavemente para prevenir espuma, e a mistura foi incubada a $30^{\circ} \mathrm{C}$ por 30 min., então adicionado $1 \mathrm{~mL}$ do substrato gelatina agitado suavemente e incubado por mais $30 \mathrm{~min}$. a $30^{\circ} \mathrm{C}$. A reação foi paralisada pela adição de $3 \mathrm{~mL}$ de ácido tricloroacético (TCA) 15\% (m/v). O branco foi preparado combinando a solução a ser testada com os respectivos inibidores e o TCA, incubado e então adicionado o substrato e incubado por mais 30 min. a $30^{\circ} \mathrm{C}$. A seguir foram centrifugados a $5.000 \times g$ por 15 min.,

deixados em repouso por 30 min. e filtrados em papel Whatman $n^{0} 3$. A leitura se deu conforme descrito anteriormente.

\subsection{Gel de atividade proteolítica}

O procedimento foi realizado de acordo com a metodologia modificada de Fry et al. (1994). Amostras de sobrenadante das bactérias foram adicionadas (1:1) ao tampão de amostra (Tris-HCl 0,0625 M, pH 6,8), SDS 2,5\%, glicerol 10\%, azul de bromofenol 0,001\%) e incubadas por $30 \mathrm{~min}$. a $30^{\circ} \mathrm{C}$. Amostras aplicadas ao gel, composto de $9 \%$ de gel de separação contendo gelatina 1\% (sem SDS) e 4\% de gel de concentração. A corrida eletroforética ocorreu a $100 \mathrm{~V}$ e $5^{\circ} \mathrm{C}$. O gel foi lavado com 2,5\% Triton X-100 por 2 h., na temperatura de $28-30^{\circ} \mathrm{C}$ e incubado em tampão fosfato $50 \mathrm{mM}$ (pH 7) a temperatura ambiente. Para a coloração do gel foi utilizado azul de Coomassie 0,1\% em metanol 40\% e ácido acético 10\% por 15 min. e descolorido com ácido acético 10\%. 


\section{RESULTADOS E DISCUSSÕES}

\subsection{Perfil de crescimento bacteriano}

Sob as condições experimentais avaliadas, os isolados de $X$. fastidiosa provenientes de diferentes espécies vegetais, apresentaram taxa de crescimento significativamente distintas.

A Figura 1 apresenta os perfis de crescimento, sendo que, os isolados que apresentaram a maior taxa de crescimento foram os de videira (9713 e Temecula), sua fase exponencial (log) iniciou-se durante o $2^{\underline{0}}$ e $3^{\underline{0}}$ dia após o inóculo e estendeu-se até o $4^{\underline{0}}$ e $5^{\underline{0}}$ dia de cultivo. Já os isolados de citros ( $\mathrm{X}_{0}$, SR3 e SR28) apresentaram fase log que se iniciou no $6^{\underline{0}}$ dia e estendeu-se até ao $10^{\circ}, 12^{\circ}$ e $14^{\circ}$, respectivamente. 


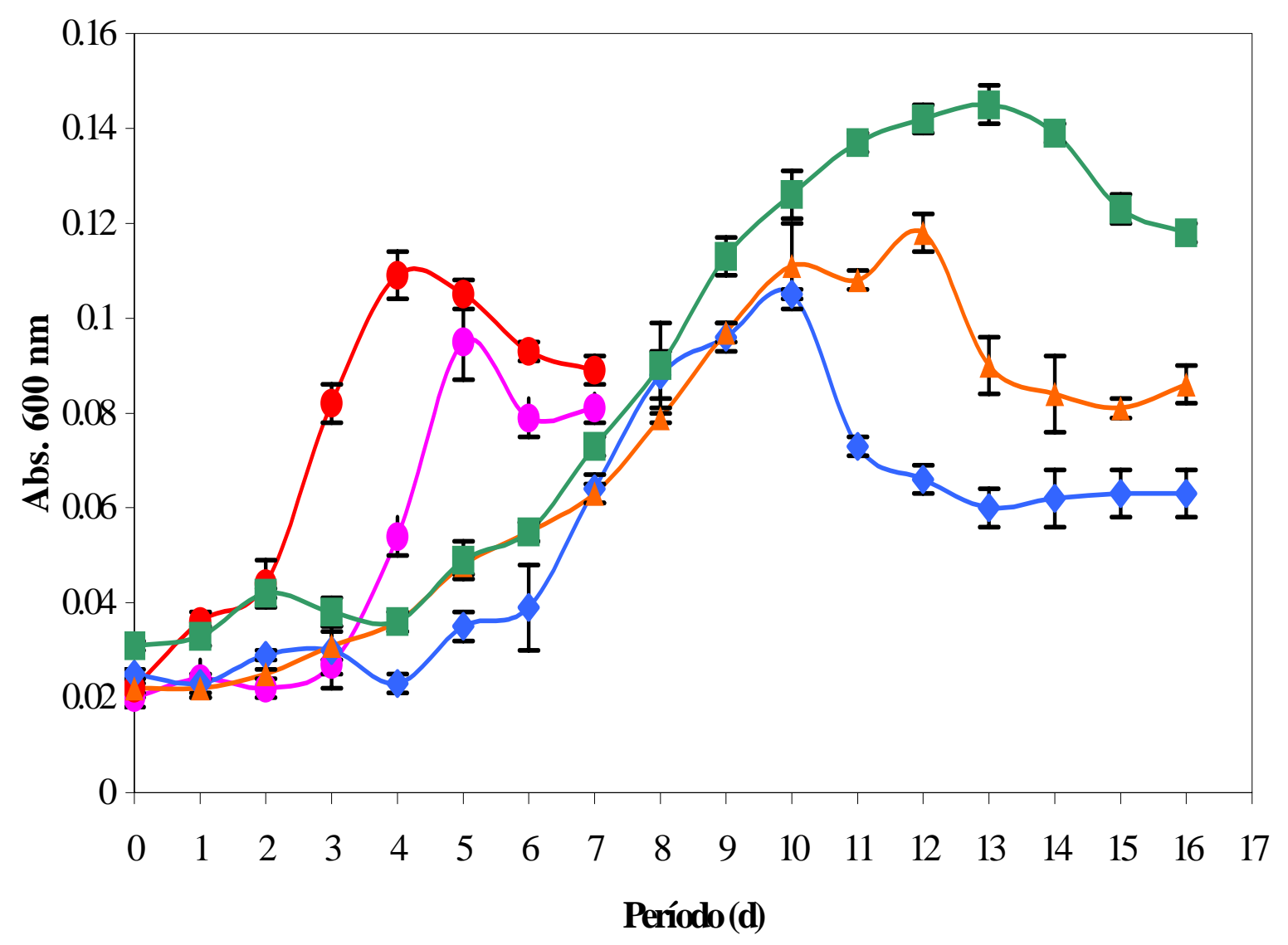

Figura 1. Curva de crescimento de $X$. fastidiosa em meio PW. Isolados: 9713 videira (๑);

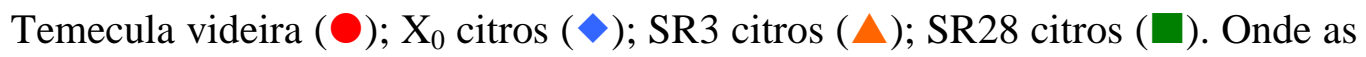
barras de erros não aparecem, o erro padrão das triplicatas foi menor do que o símbolo apresentado.

As características visuais também apresentaram alguma divergência entre os diferentes hospedeiros (videira e citros), as células se apresentaram mais agregadas nos citros quando comparadas com videira.

A X. fastidiosa tem a característica de não apresentar valores elevados de absorbância (máximo de 0,15 a $600 \mathrm{~nm}$ ) utilizando-se o meio PW como pode ser constatado no estudo de Campanharo et al. (2003) que compararam diferentes meios de cultivo e o meio PW apresentou o menor valor de absorbância a $600 \mathrm{~nm}(0,15)$. 


\subsection{Proteínas totais}

Proteínas totais foram quantificadas através da metodologia de Bradford (1976). Alíquotas foram quantificadas diariamente com o intuito de conhecer qual o período (d) de maior produção de proteínas (enzimas).

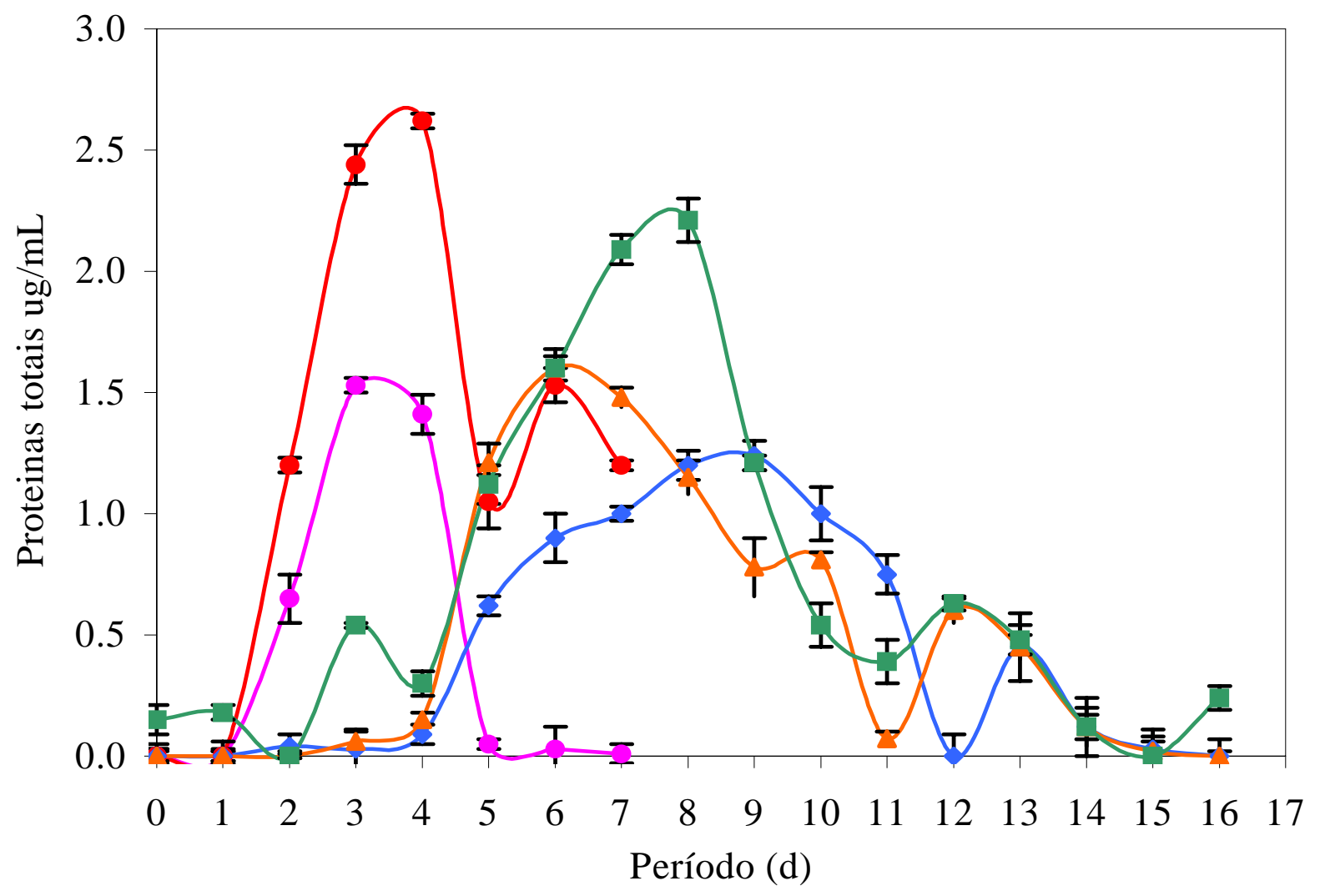

Figura 2. Proteína total extracelular de isolados de citros e videira. Isolados: 9713 videira $(\bigcirc)$; Temecula videira $(O) ; \mathrm{X}_{0}$ citros $(\diamond)$; SR3 citros $(\Delta)$; SR28 citros (ם).Onde as barras de erros não aparecem, o erro padrão das triplicatas foi menor do que o símbolo apresentado. 
Proteínas foram mais intensamente produzidas no início da fase log de crescimento, sendo indício de que a bactéria produz mais proteínas antecedente ao seu crescimento.

Não foi possível detectar a produção de proteases diariamente, pois estas foram produzida em baixa concentração, para este tipo de análise o sobrenadantes das culturas foram coletados no período de maior produção de proteínas extracelulares, correspondentes ao $3^{0}$ dia de crescimento para $X$. fastidiosa de videira e $6^{0}$ dia para citros. Conforme estudos realizados por Ribeiro et al. (2001), as células bacterianas do isolado 9a5c de $X$. fastidiosa $\left(\mathrm{X}_{0}\right)$, ao $6^{0}$ e $11^{0}$ dias, encontravam-se no ínicio e no final da fase log, respectivamente. Isso significa que essas estavam metabolicamente ativas no período de coleta.

Fry (1994) observou uma relação entre crescimento de $X$. fastidiosa PD (videira) e atividade de protease em meio PD3, sendo que maior crescimento e produção de protease foi atingido por volta do $3^{\underline{0}}$ dia de cultivo seguido de posterior decréscimo. Uma similar correlação entre crescimento e produção de proteases em culturas de Erwinia chysanthemi foi também relatada por Barras (1986).

\subsection{PCR}

A Figura 3 ilustra a amplificação do fragmento referente ao gene ribossômico 16S de $X$. fastidiosa. Todos os isolados apresentaram fragmentos amplificados de $745 \mathrm{pb}$, indicando que todos os isolados são de espécie $X$. fastidiosa.

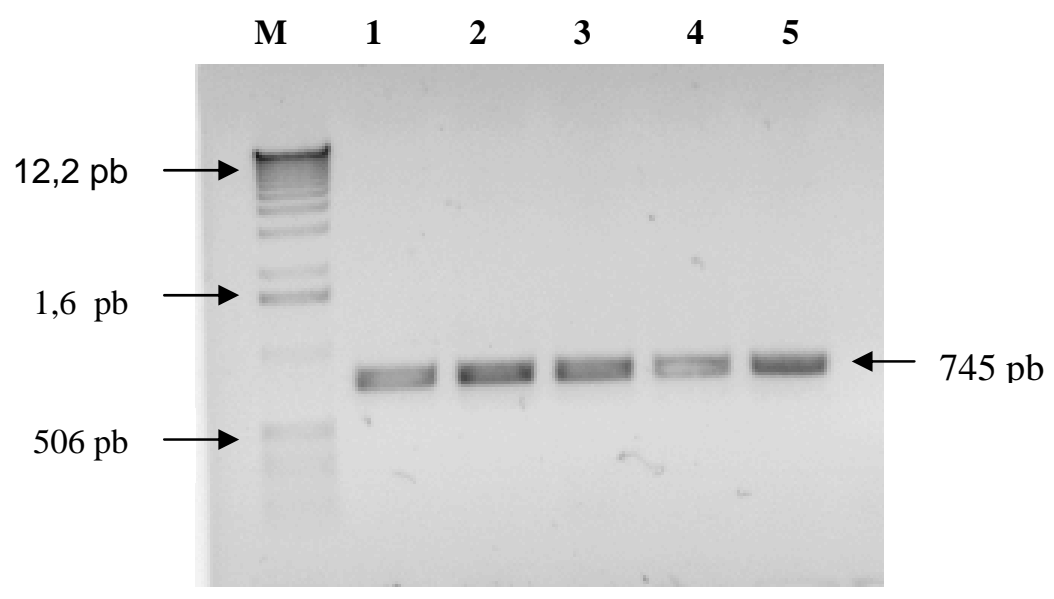


Figura 3. Produto de PCR analisado em gel de agarose 1,0\% e corado com brometo de etídeo, usando-se primers específicos para o gene ribossômico 16S de $X$. fastidiosa. M) marcador molecular $1 \mathrm{~Kb}$; 1) X $\mathrm{X}_{0}$ 9a5c; 2) SR3; 3) SR28; 4) 9713videira; 5) Temécula.

\subsection{Perfil de proteínas extracelulares}

A Figura 4 mostra o perfil de proteínas extracelulares obtidas a partir de culturas bacterianas, após precipitação com sulfato de amônio. O perfil obtido apresenta proteínas com pesos moleculares de $15 \mathrm{kDa}$ a $225 \mathrm{kDa}$, sendo que as bandas com melhor definição variou entre os isolados verificados.

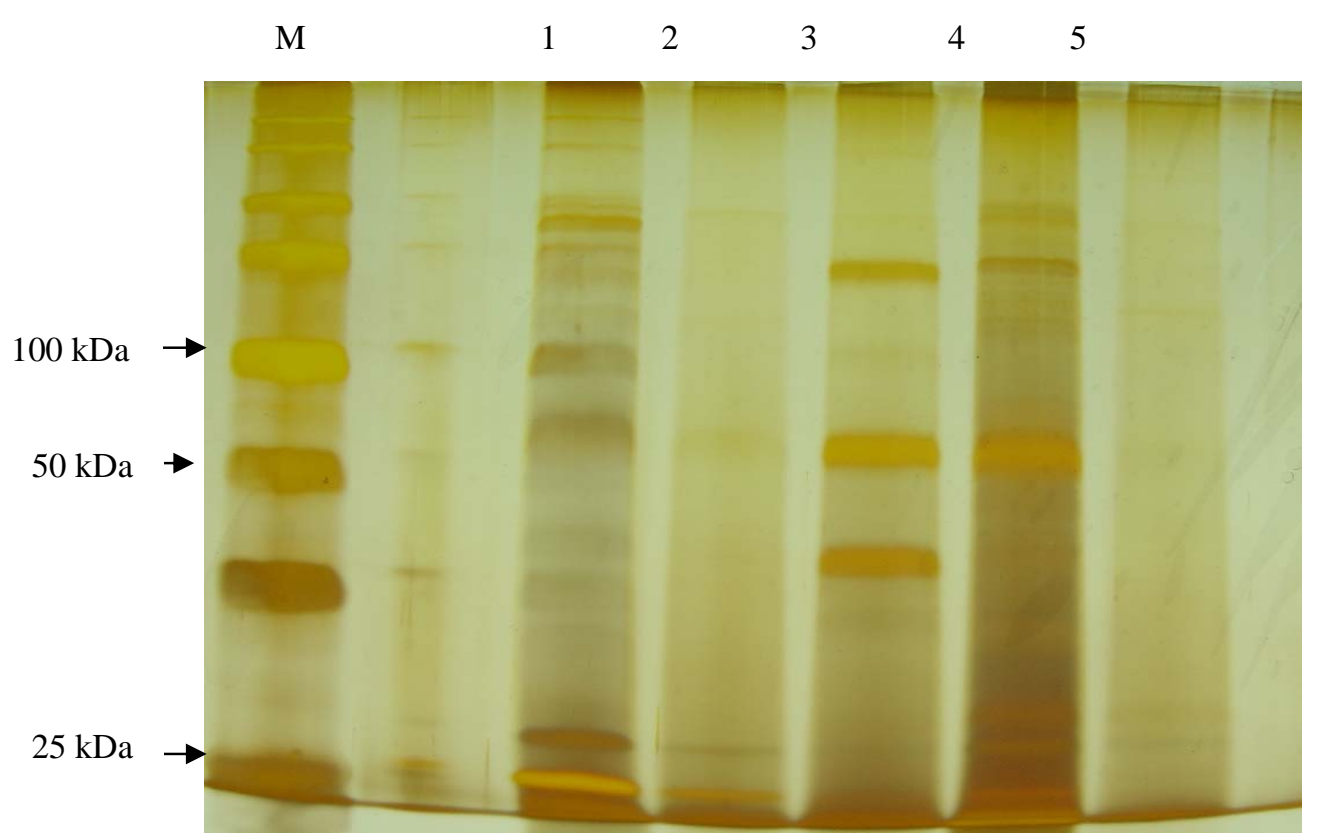

Figura 4. Perfil de proteínas extracelulares de X.fastidiosa de citros e videira: M) marcador molecular; 1) $\mathrm{X}_{0}$; 2) SR3; 3) SR28; 4) 9713; 5) Temecula. 
Segundo Rodrigues et al. (1992) há uma similaridade do perfil eletroforético de proteínas totais entre os padrões obtidos das linhagens isoladas de videira, ambrósia, ameixa e citros foi encontrada. Outros estudos com isolados de ameixa mostraram que estas não puderam ser diferenciadas pela análise de proteínas totais, o mesmo não acontece com os isolados de citros onde $\mathrm{X}_{0}$ apresentou padrões diferentes em relação às outras analisadas (Mehta et al., 2001), distinguindo-se portanto seis grupos por eletroforese em gel SDSPAGE: videira, café, $\mathrm{X}_{0}$, outros isolados de citros, ameixa e pêra.

\section{$5.5 \mathrm{pH}$ e temperatura ótimos para atividade de proteases}

Os ensaios de pHs e temperaturas evidenciaram baixa estabilidade da atividade das proteases, quando utilizada gelatina como substrato. 


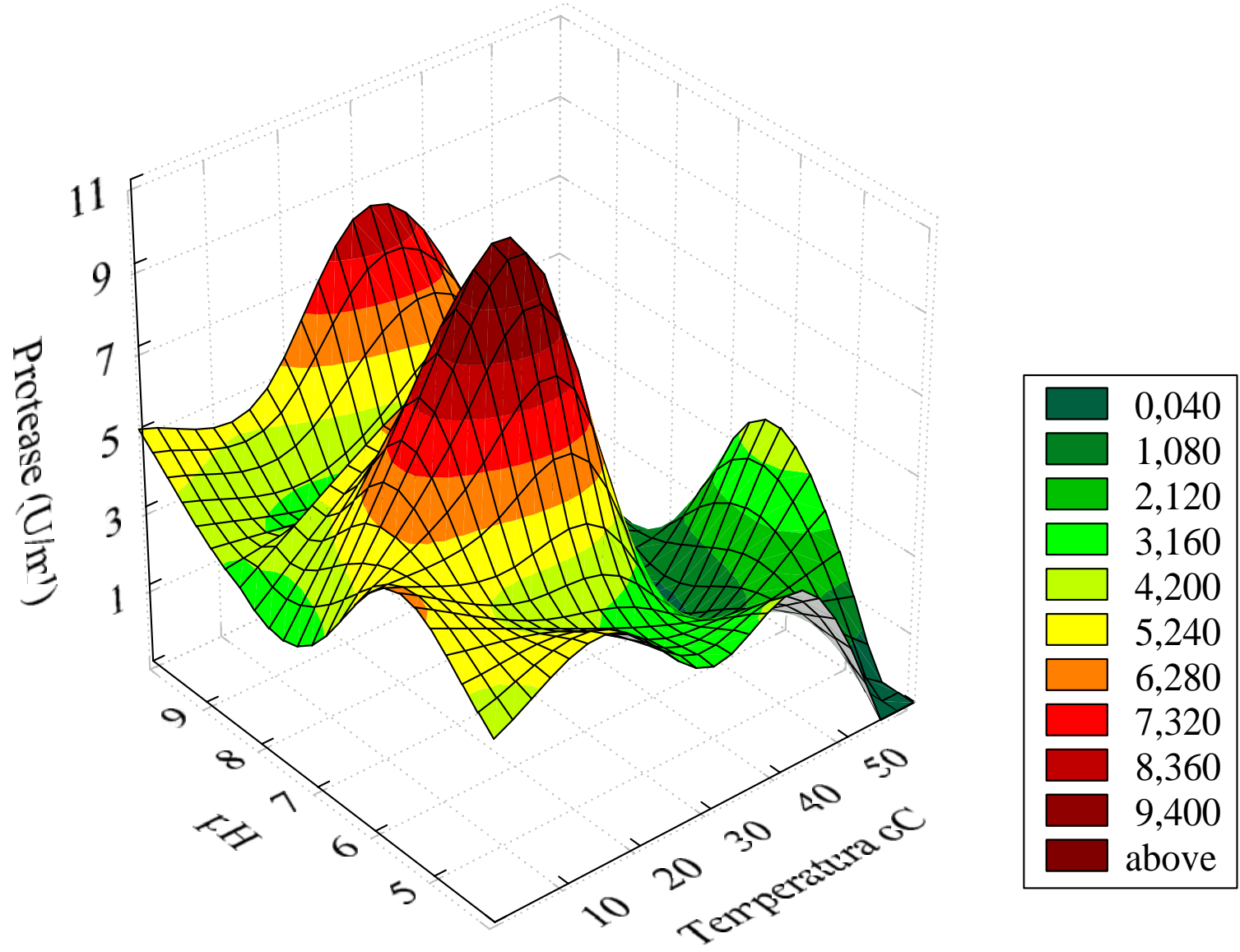

Figura 5. Atividade proteolítica de $X$. fastidiosa de citros $\left(\mathrm{X}_{0}\right)$, utilizando substrato gelatina em diferentes pHs e temperaturas.

Amostras contendo enzimas foram incubadas em diferentes temperaturas que variaram de 10 a $50^{\circ} \mathrm{C}$, sendo que a máxima atividade enzimática foi observada entre 20 e $30^{\circ} \mathrm{C}$ a qual decresceu subitamente após incubação em temperatura superior a $40^{\circ} \mathrm{C}$, sendo esta enzima sensível a altas temperaturas. Segundo Fry et al. (1994) a máxima atividade de protease de $X$. fastidiosa $\mathrm{PD}$ (videira) foi a $50^{\circ} \mathrm{C}$ e decresceu drasticamente quando a temperatura foi de 60 a $65^{\circ} \mathrm{C}$, sendo totalmente inibida a $70^{\circ} \mathrm{C}$. 
A atividade proteolítica foi também verificada para pHs na faixa de 5,0 a 9,0, sendo que o ótimo de pH foi entre 6,0 e 7,0. De acordo com Fry et al. (1994) proteases de $X$. fastidiosa PD (videira) apresentaram atividade ótima de $\mathrm{pH}$ em torno de 9,0.

Protease de Xanthomonas c. pv. campestris (Dow et al., 1990) apresentaram máxima atividade em $\mathrm{pH}$ 8,0, já a atividade de protease de Erwinia c. subsp. carotovora (Smith et al., 1987) teve ótimo pH em torno de 7,0 e Xanthomonas c. pv. oryzae (Fuji \& Vematsu, 1975) teve ótimo de $\mathrm{pH}$ de aproximadamente 9,3 a temperatura de $40^{\circ} \mathrm{C}$.

A atividade proteolítica de E. chrysanthemi foi resistente a temperaturas superior a $50^{\circ} \mathrm{C}$ (Barras et al., 1986), sendo a Erwinia. c. subsp. Carotovora resistente a temperaturas superiores a $100^{\circ} \mathrm{C}$ (Willis et al., 1987), segundo Sun. (1991) a máxima atividade

proteolítica de $X$. c. pv. zinniae foi de $50^{\circ} \mathrm{C}$, porém apresentou resistência a temperaturas superiores a $65^{\circ} \mathrm{C}$. A espécie Erwinia amylovora isolado E8 apresentou atividade proteolítica ótima a $37^{\circ} \mathrm{C}$ (Zhang et al., 1999).

\subsection{Determinação semi-quantitativa de quitinase e $\beta$-glucanase}

Atividade quitinolítica e de $\beta$-glucanase foram detectadas no sobrenadante de $X$. fastidiosa de citros $\left(\mathrm{X}_{0}\right)$, as quais foram indicadas pela formação de zonas mais claras ao redor do sobrenadante aplicado às placas contendo substrato. O aparecimento de halos ocorreu durante 3 a 5 dias de incubação a $30^{\circ} \mathrm{C}$. Em pH 7,5 a atividade quitinolítica pôde ser detectada, enquanto que para a $\beta$-glucanase o melhor $\mathrm{pH}$ foi 5,5.

A presença de halos ao redor dos pocinhos foi avaliada como atividade enzimatica. 


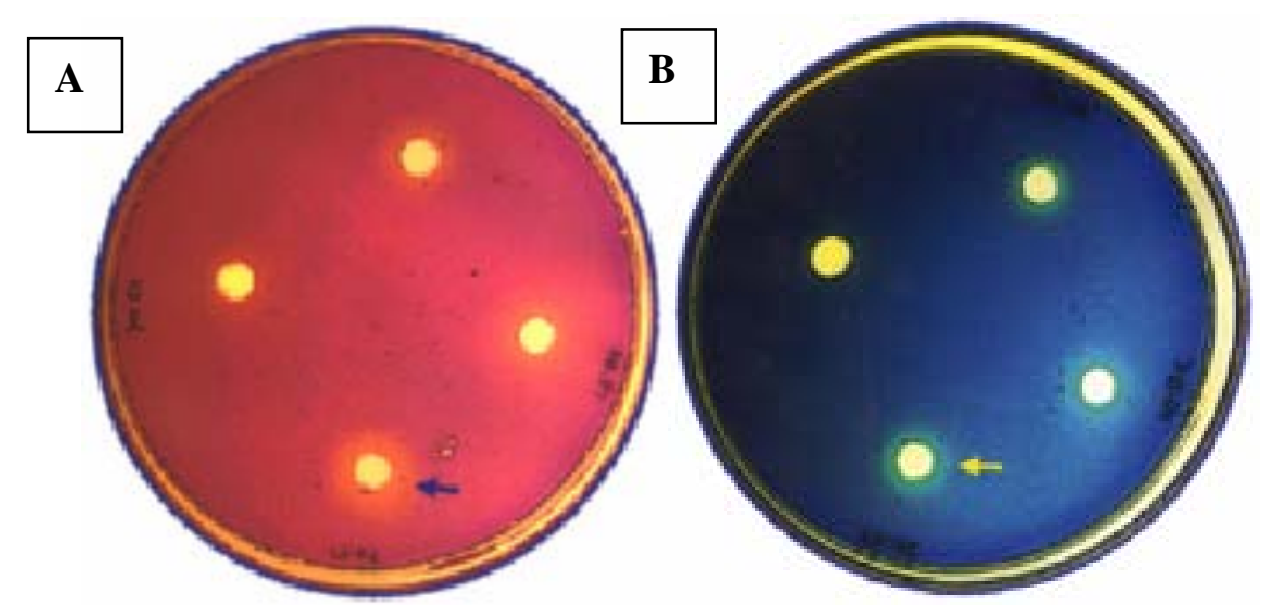

Figura 6. Formação de halos indicando a presença de quitinase (A) e $\beta$-1,3-glucanase (B) no sobrenadante de $X$. fastidiosa de citros $\left(\mathrm{X}_{0}\right)$.

As enzimas comumente associadas com interação hospedeiro-patógeno são: poligalacturonase, pectatoliase, pectinaliase, pectin metil liase, pectin metil esterase, protease, celulases, $\beta$-1,3-glucanase e $\beta$-1,4-glucanase (Iannetta et al., 1997). O fitopatógeno Erwinia carotovora subsp. carotovora produz diferentes tipos de enzimas relacionadas com virulência incluindo isoformas de pectato liase, pectina liase, polygalacturonase, celulase e protease (Collmer \& Kenn, 1986).

\subsection{Hidrólise em substrato}

Zonas de hidrólise foram observadas em todos os substratos utilizados (Tabela 1). Todos os isolados hidrolisaram preferencialmente gelatina quando comparados com caseína e hemoglobina, um branco (meio PW) foi utilizado como controle negativo. 
Tabela 1. Diferentes substratos utilizados para detecção de atividade de protease de $X$. fastidiosa.

\begin{tabular}{|l|c|c|c|}
\hline \multirow{2}{*}{ Bactérias } & \multicolumn{3}{|c|}{ Diâmetro do halo (mm) } \\
\cline { 2 - 4 } & Gelatina & Caseína & Hemoglobina \\
\hline $\mathrm{X}_{0} 9$ a5c (citros) & 2 & nd & 1 \\
\hline SR3 (citros) & 7 & 1 & 3 \\
\hline SR28 (citros) & 5 & nd & 1 \\
\hline 9713 (videira) & nd & nd & nd \\
\hline Temécula (videira) & 1 & 1 & \\
\hline
\end{tabular}

n.d. = não determinado
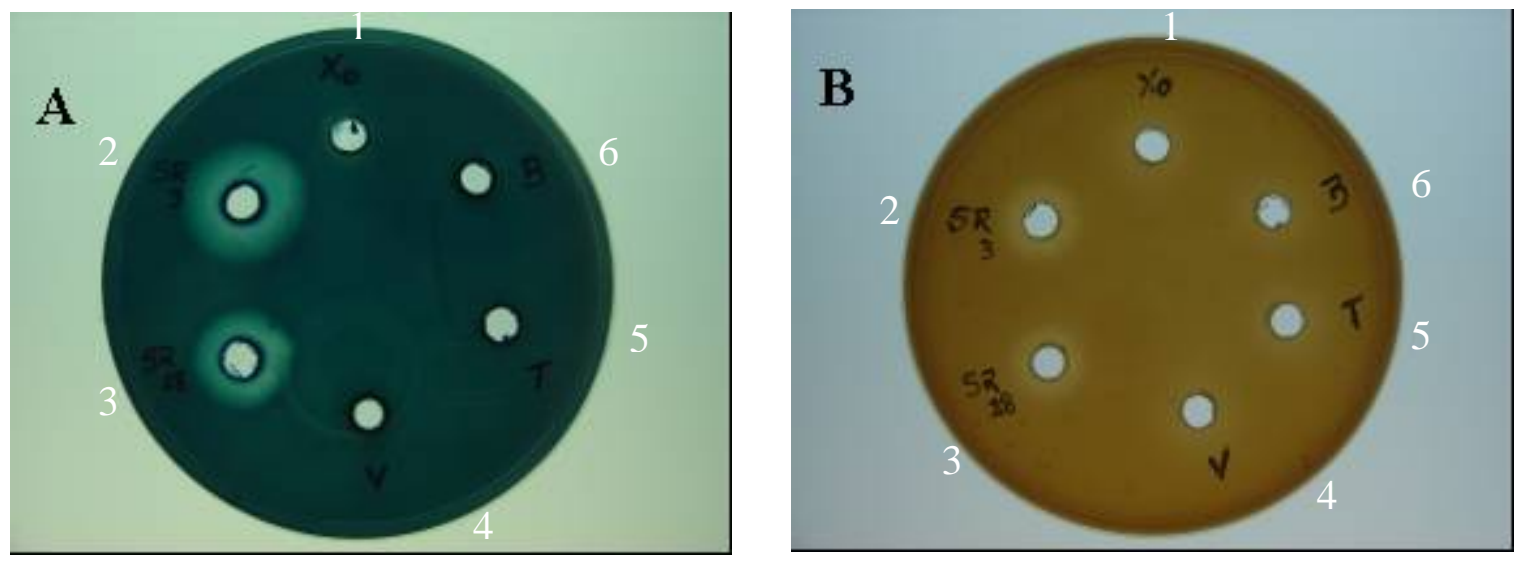

Figura 7. Formação de halos em substrato gelatina (A) e hemoglobina (B) indicando a presença de enzimas proteolíticas no sobrenadante dos isolados de $X$. fastidiosa. Sendo: isolados de citros; 1, Xo; 2, SR3; 3, SR28 e de videira; 4, 9713; 5, 
temecula. 6, branco. Foram adicionados $100 \mu \mathrm{L}$ do sobrenadante (a cada 12 horas). As placas foram incubadas a $30^{\circ} \mathrm{C}$ por 3 dias.

De acordo com Fry et al. (1994), estudos revelaram que proteases de .X.fastidiosa PD (Pierce's disease) degradaram gelatina e azocaseína em solução, sendo que a gelatina foi o melhor substrato para determinação da atividade proteolítica. Wells et al. (1987) descreveram que um isolado de $X$. fastidiosa produziu gelatinase em meio PW sendo esta detectada por teste de gelatina- charcoal.

Fry et al. (1994) verificaram que todos os isolados de X. fastidiosa PD (videira) cultivados em meio PD3 sólido acrescido de 1\% de gelatina produziram zonas de hidrólise, porém as zonas de hidrólise foram difusas, provavelmente indicando uma pequena quantia de protease produzida pelos isolados, uma vez que, quando utilizado proteases purificadas comercialmente, obteve-se zonas de hidrólise com bordas bem definidas.

Similarmente outras bactérias patogênicas de plantas foram capazes de degradar proteínas. Dentre elas: Xanthomonas alfafa (Reddy et al., 1971) degradou caseína e gelatina. Erwimia.c.subsp.carotovora degradou gelatina, caseína, caseína hidrolisada e albumina de soro bovina; porém, gelatina foi o melhor substrato (Tseng \& Mount, 1975), gelatina foi também o melhor substrato para a metalo protease do isolado E8 de Erwinia amylovora (Zhang et al., 1999), Erwinia chrysanthemi degradou azocaseina (Sinhá \& Prasad, 1983) e gelatina (Barras et al., 1986)., Xanthomonas campestris pv. zinniae degradou gelatina, caseína, albumina de soro bovina e colágeno, sendo aparentemente caseína o melhor substrato (Sun, 1991).

Aoki et al. (1994) examinaram oito linhagens de Cryptococcus neoformans var. neoformans quanto a capacidade de produzir proteases extracelulares. Todas as linhagens produziram zona clara de proteólise ao redor das colônias, quando cultivadas em meio YCB agar suplementado com albumina de soro bovino e polipeptona.

Heilbronn et al. (1995) purificaram uma metalo protease extracelular de Erwinia. c. subsp. carotovora, capaz de degradar azocaseina e leite desnatado e lentamente foi também capaz de degradar lectina de batata. 


\subsection{Quantificação de proteases após precipitação com sulfato de amônio}

Por apresentar baixa concentração de proteases o sobrenadante dos isolados de $X$. fastidiosa foram fracionados com sulfato de amônio 90\% de saturação.

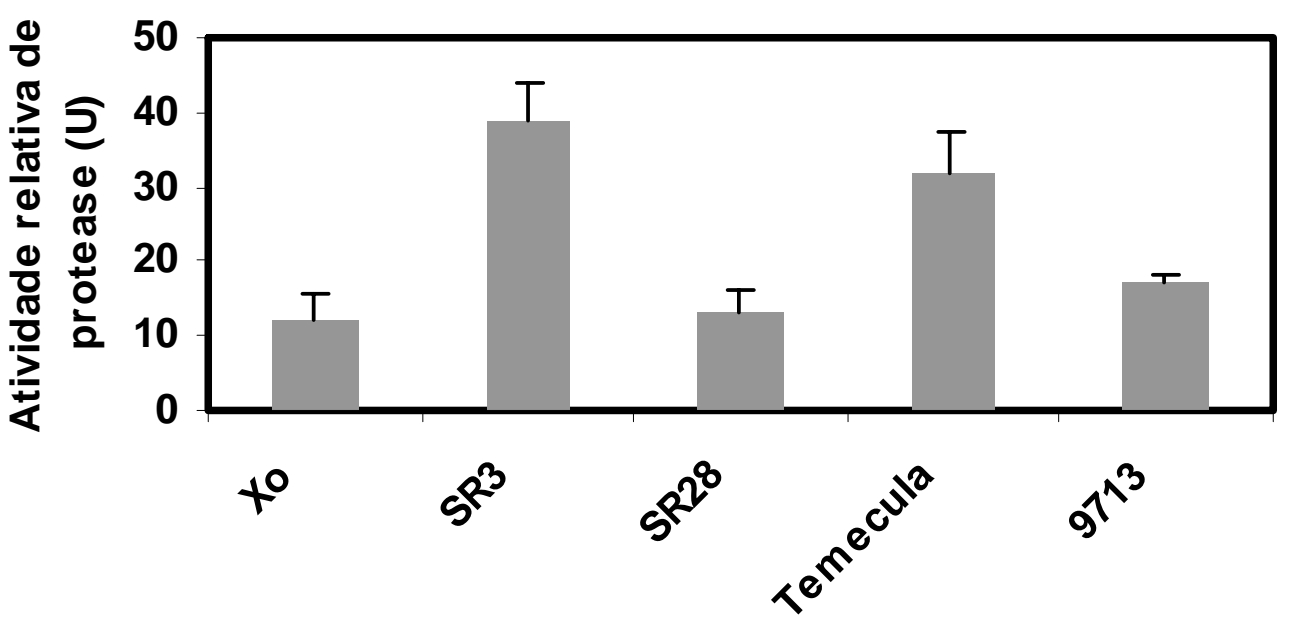

Isolados

Figura 8. Atividade relativa de protease após saturação com sulfato de amônio (90\%), utilizando gelatina como substrato, temperatura de $30^{\circ} \mathrm{C}$ e $\mathrm{pH}$ 7.0. Uma unidade de atividade enzimática foi definida como a quantidade de enzima requerida para causar um aumento de 0,1 unidade na absorbância a $280 \mathrm{~nm}$ sob as condições do ensaio.

Amostras precipitadas com sulfato de amônio foram fracionadas a 65\% e 90\% de saturação e posteriormente dialisadas, foram quantificadas, e então utilizada amostras de 90\% de saturação por apresentarem maior diversidade e concentração de proteases.

As frações de 65\% apresentaram-se menos significativas. Estes resultados contradiz com os apresentados com Fry et al. (1994) que obteve maior atividade de proteases 
oriundas de outros isolados de videira (PD) na fração de 41-50\% de sulfato de amônio, sendo que as duas proteases denominadas pelo autor de P1 e P2 estiveram presentes em similar quantidade.

\subsection{Inibidores enzimáticos}

A fim de distinguir entre as quatro classes de proteases: serina, cisteína, aspártico e metalo proteases, vários inibidores específicos foram utilizados.

O efeito destes inibidores na atividade proteolítica de $X$. fastidiosa estão apresentados nas Figuras 9 e 10.
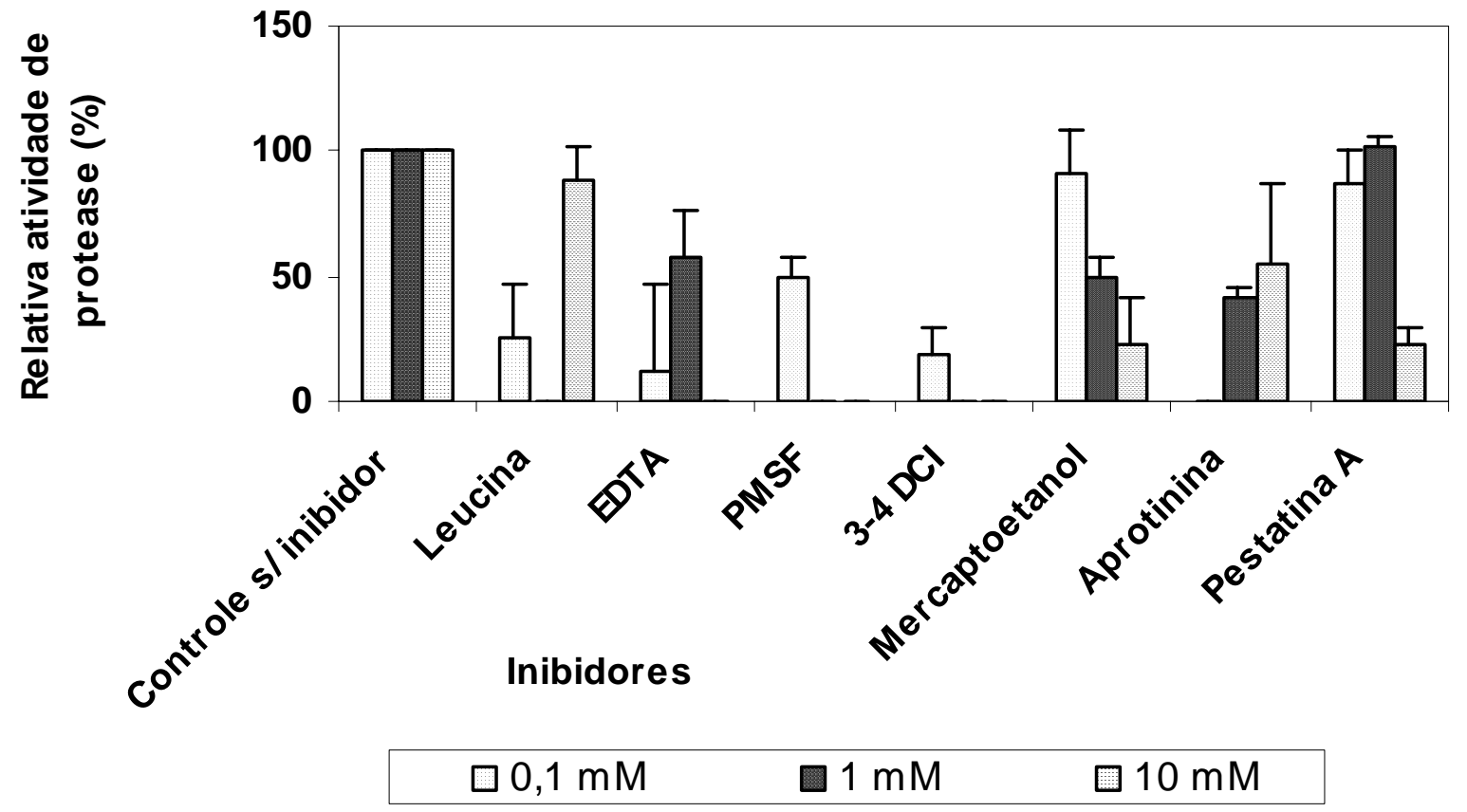

Figura 9. Efeito de inibidores na atividade de proteases de $X$. fastidiosa de citros $\left(\mathrm{X}_{0}\right)$, 
pH 7,0 e $30^{\circ} \mathrm{C}$, em meio PW. Classificação dos inibidores: Leucina e EDTA inibidores de metalo proteases; PMSF e 3-4 DCI inibidores de serina protease; $\beta$-mercaptoetanol inibidor de cisteína protease; Aprotinina inibidor de serina e cisteína protease e Pestatina A inibidor de aspártico protease.

A atividade de protease de $X$. fastidiosa de citros $\left(\mathrm{X}_{0} 9 \mathrm{a} 5 \mathrm{c}\right)$ foi completamente inibida por: Leucina (1 mM), EDTA (10 mM), PMSF (1 e $10 \mathrm{mM}), 3-4$ DCI (1 e $10 \mathrm{mM})$ e Aprotinina $(0,1 \mathrm{mM})$.

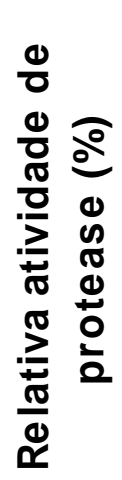

150
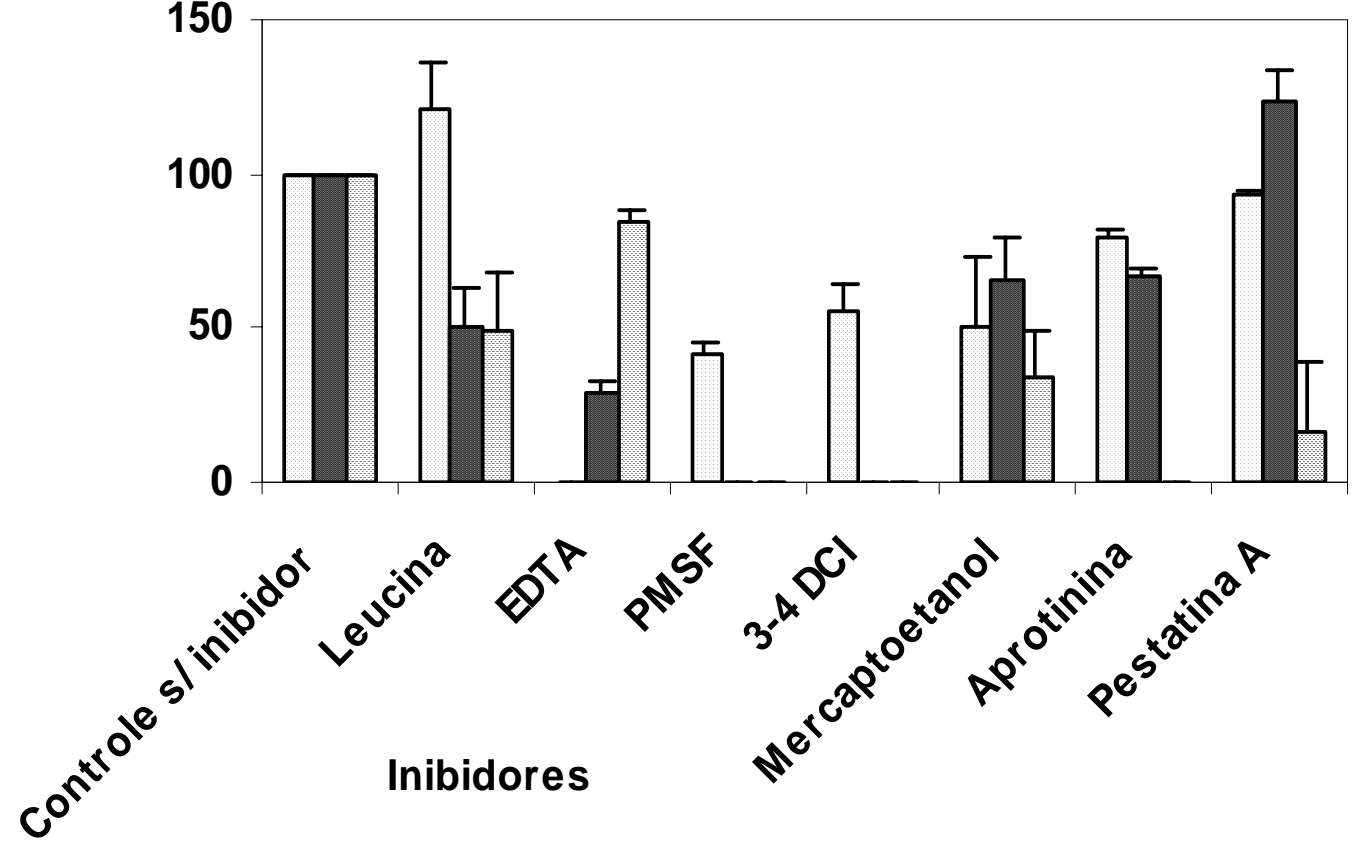

\section{Inibidores}

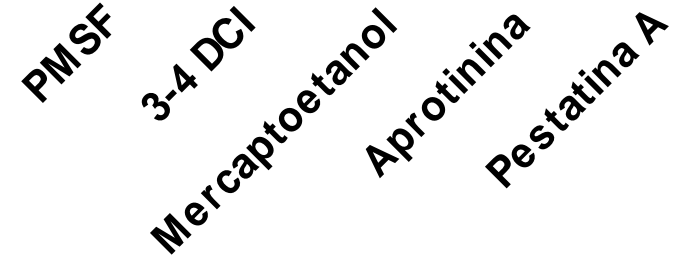

$\square 0,1 \mathrm{mM} \quad \square 1 \mathrm{mM} \quad \square 10 \mathrm{mM}$

Figura 10. Efeito de inibidores sobre atividade de proteases de $X$. fastidiosa de videira (9713), pH 7,0 e $30^{\circ} \mathrm{C}$, em meio PW. Classificação dos inibidores: Leucina e EDTA inibidores de metalo proteases; PMSF e 3-4 DCI inibidores de serina 
protease; $\beta$-mercaptoetanol inibidor de cisteína protease; Aprotinina inibidor de serina e cisteína protease e Pestatina A inibidor de aspártico protease.

A atividade de protease de $X$. fastidiosa de videira (9713) foi completamente inibida por EDTA (0,1 mM), PMSF ( 1 e $10 \mathrm{mM}$ ), 3-4 DCI (1 e $10 \mathrm{mM}$ ) e Aprotinina (10 mM).

Estes inibidores sugerem que proteases extracelulares de $X$. fastidiosa de citros e de videira possam pertencer à classe das serina e metalo proteases, devido ao fato destas terem sido completamente inibidas por PMSF e 3-4 DCI (inibidores específicos de serina protease) e parcialmente inibidas por EDTA e Leucina (inibidores específicos de metalo protease).

Tanto o isolado de $X$. fastidiosa de citros como o de videira tiveram aumento na atividade proteolítica quando utilizado Pepstatina A (1 mM), o qual foi confirmado com um aumento na intensidade da banda, quando amostras de proteases contendo Pepstatina A foram aplicadas em gel de eletroforese-nativo. Todos os outros inibidores testados não afetaram significativamente a atividade proteolítica.

A protease encontrada em Erwinia chrysanthemi isolado HP3 (Wandersman et al., 1986) é uma serina protease a qual somente é afetada por PMSF e não por EDTA.

A bactéria Erwinia amylovora isolado E8 produz uma protease extracelular, a qual foi caracterizada como sendo uma metalo protease sendo completamente inibida por Fenantrolina (1mM) e parcialmente inibida por EDTA (1mM), ambos inibidores de metalo protease (Zhang et al., 1999).

A protease PRT1 de Xanthomonas c. pv campestris foi completamente inibida por PMSF e EDTA sugerindo esta ser uma serina protease que também requer íon para sua atividade e/ou estabilidade (Dow et al., 1990).

Bactérias sintetizam variedade de proteases, porém aspártico proteases não tem sido encontradas em bacterias (Neurath, 1989; Romero et al., 2001). 


\subsection{Efeito de cátions na atividade de proteases extracelulares de $X$. fastidiosa}

Com o intuito de verificar qual a influencia de alguns cátions sob a atividade proteolítica de $X$. fastidiosa, e também se estes podem estar atuando como cofatores na atividade enzimática. Amostras foram incubadas com diferentes íons.

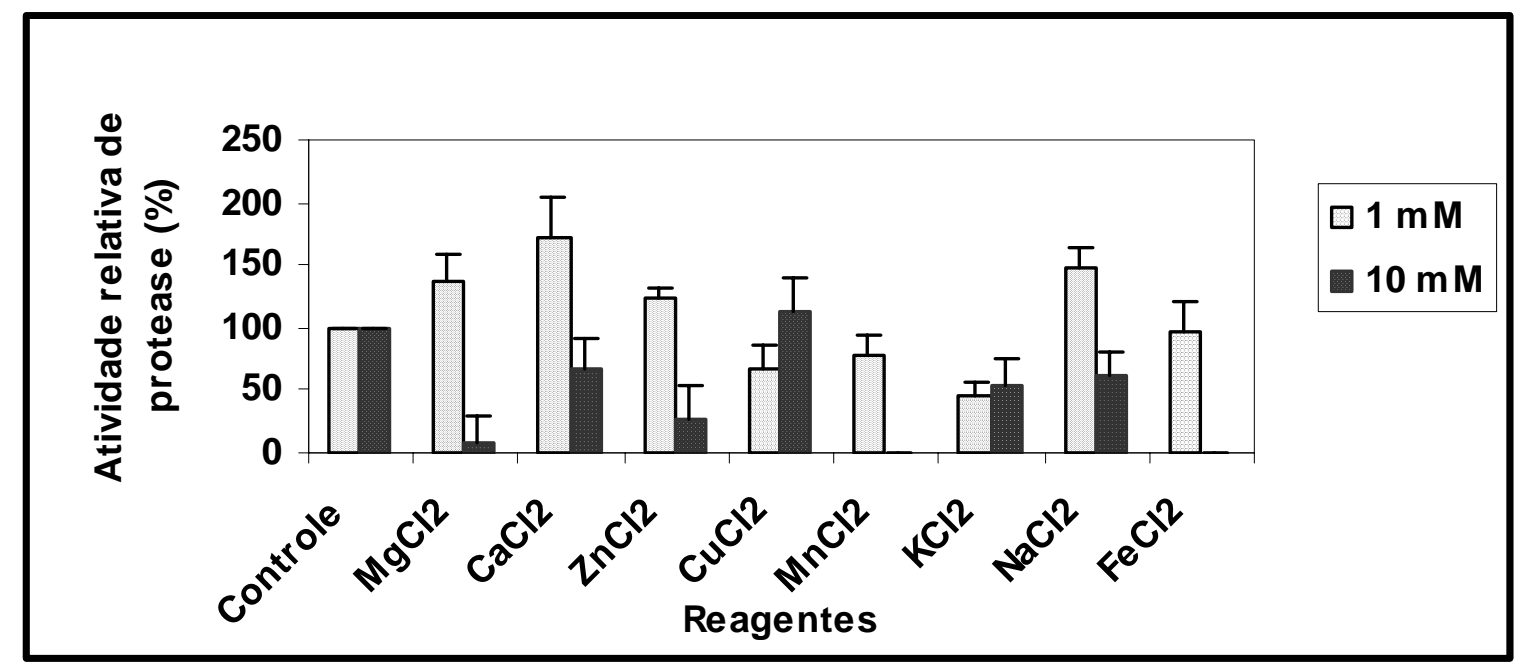

Figura 11. Efeito de cátions sobre a atividade de proteases de $X$. fastidiosa de citros (pH 7,0 e $\left.30^{\circ} \mathrm{C}\right)$, em meio PW.

A atividade enzimática de $X$. fastidiosa de citros foi completamente inibida por $\mathrm{MnCl}_{2}$ (10 mM ) e $\mathrm{FeCl}_{2}(10 \mathrm{mM})$.

A atividade enzimática de $X$. fastidiosa de citros $\left(\mathrm{X}_{0}\right)$ foi elevada usando-se, $\mathrm{CaCl}_{2}$ $1 \mathrm{mM}$ (172\%), $\mathrm{NaCl}_{2} 1 \mathrm{mM}$ (147\%) e $\mathrm{MgCl}_{2} 1 \mathrm{mM}$ (136\%), sendo que o maior aumento na atividade foi obtido com o $\mathrm{CaCl}_{2}$. De acordo com alguns autores os íons cálcio são importantes para a catálise enzimática. James et al. (1991) sugeriram que presumivelmente estes íons estabilizam a proteína através de sítios de ligação específicos ou não específicos e podem também permitir ligações adicionais na molécula da enzima, prevenindo 
desnaturação em temperatura mais altas, como tem sido demonstrado para proteases de bactérias termofilicas, particularmente termolisina.

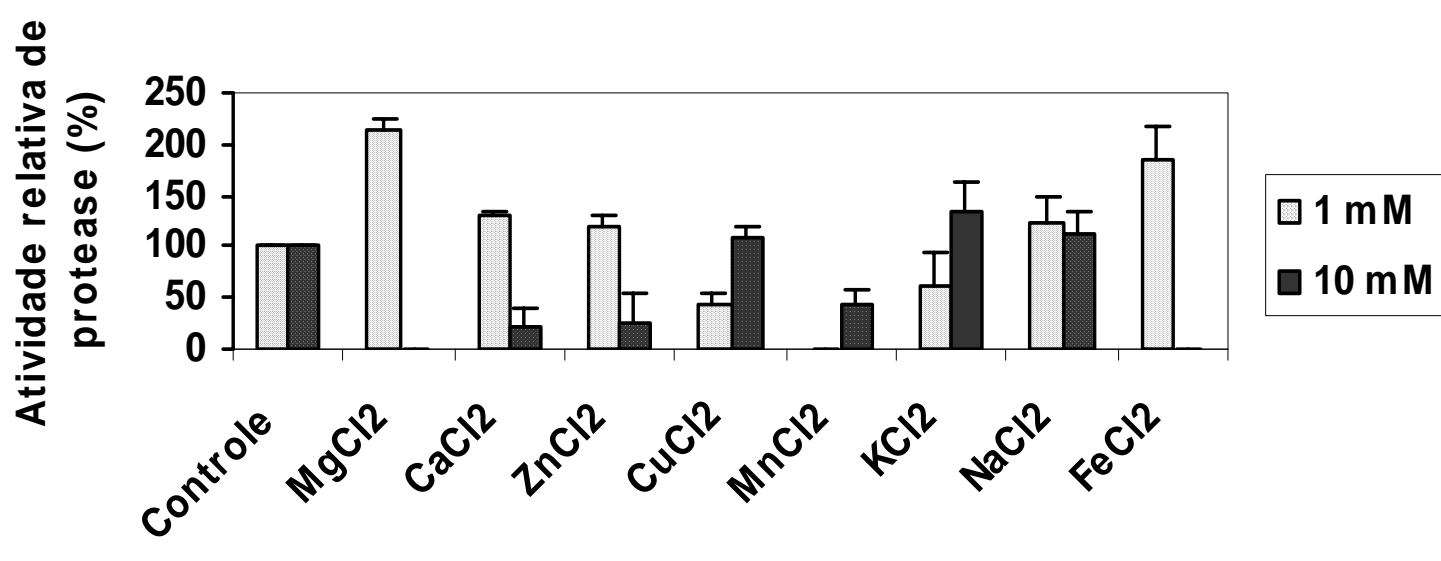

Reagentes

Figura 12. Efeito de cátions na atividade de proteases extracelulares de $X$. fastidiosa de videira (9713), $\mathrm{pH} 7,0$ a $30^{\circ} \mathrm{C}$ em meio $\mathrm{PW}$.

A atividade enzimática de $X$. Fastidiosa de videira (9713) foi completamente inibida por $\mathrm{MgCl}_{2} 10 \mathrm{mM}, \mathrm{MnCl}_{2} 1 \mathrm{mM}$ e $\mathrm{FeCl}_{2} 10 \mathrm{mM}$. Redução da atividade de protease de $X$. fastidiosa PD (videira) foi observado anteriormente quando $\mathrm{Zn}^{+2}$ foi utilizado (Fry et al., 1994).

A atividade enzimática de $X$. fastidiosa de videira (9713) foi aumentada por $\mathrm{MgCl}_{2}$ $1 \mathrm{mM}(212 \%)$ e $\mathrm{FeCl}_{2} 1 \mathrm{mM}$ (186\%).

$X$. fastidiosa de videira apresentou maior atividade na presença de alguns íons, como o $\mathrm{MgCl}_{2}$, quando comparado com o aumento da atividade proteolítica que este foi capaz de provocar em $X$. fastidiosa de citros.

Proteases de $X$. fastidiosa de citros e videira utilizaram íons metais para sua estabilidade ou para aumento de sua atividade, ao passo que alguns íons também acabaram inibindo a atividade proteolítica. Estas proteases podem ser metalo proteases, as quais estão 
utilizando íons como cofatores ou então são serina proteases, que utilizam íons para aumento de atividade enzimática.

Bactérias fitopatogênicas também produzem metalo proteases, as quais geralmente depende de íons para sua atividade. Erwinia. c. subsp. carotovora Ecc71 produziu uma metalo protease que requer $\mathrm{Ca}^{+2}$ para a máxima atividade (Willis et al., 1987) já a isolado EC14 produziu uma metalo protease que requer $\mathrm{Zn}^{+2}$ (Kyostio et al., 1991). E. chrysanthemi isolado B374 produziu uma metalo protease onde $\mathrm{Mg}^{+2}$ e $\mathrm{Ca}^{+2}$ aumentaram sua atividade (Delepelaire \& Wandersman, 1989). Dow et al. (1990), relataram que Xanthomonas c. pv. Campestris produziu duas proteases; uma serina protease que requer $\mathrm{Ca}^{+2}$ e uma metalo protease a qual tem a atividade estabilizada com $\mathrm{Zn}^{+2}, \mathrm{Ca}^{+2}, \mathrm{Mn}^{+2}$ e $\mathrm{Mg}^{+2}$. Protease de Xanthomonas c.pv. zinniae (Sun, 1991) parece ser uma metalo protease porém $\mathrm{Ca}^{+2}$ e $\mathrm{Mg}^{+2}$ não afetaram a atividade, ao passo que $\mathrm{Zn}^{+2}$ e $\mathrm{Mn}^{+2}$ diminuíram a atividade.

\subsection{Temperatura ótima de proteases}

Para confirmar a atividade ótima das proteases verificadas anteriormente na Figura 5. Amostras, incubadas a diferentes temperaturas, foram aplicadas em gel. 


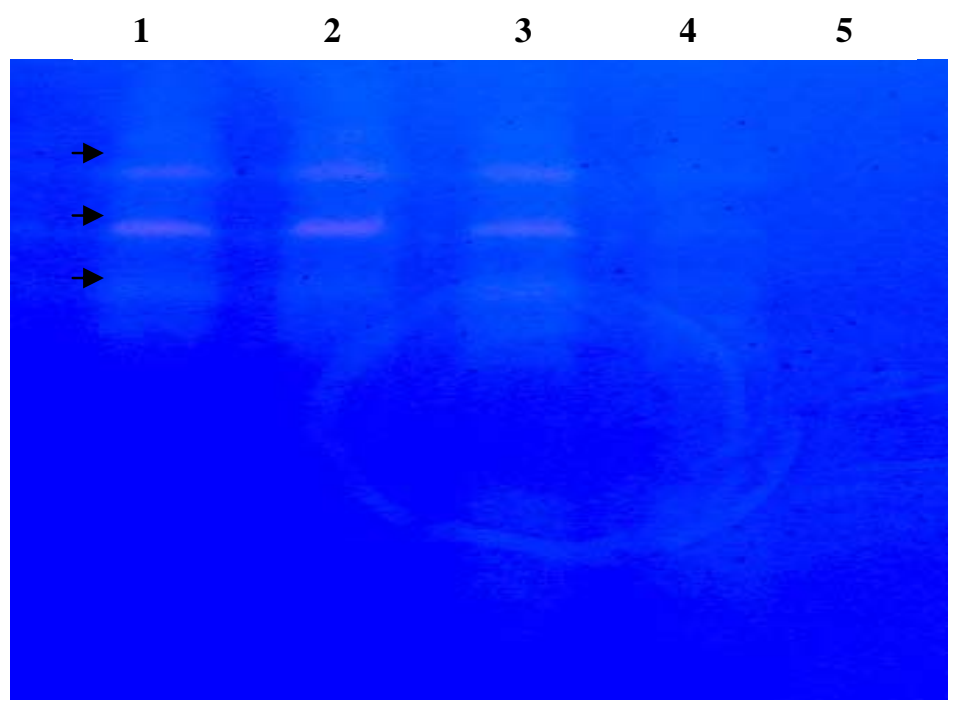

Figura 13. Proteases extracelulares de $X$. fastidiosa de citros $\left(\mathrm{X}_{0}\right)$ em gel nativo substrato gelatina $1 \%$ e corado com azul de Coomassie, amostras incubadas a diferentes temperaturas. Colunas: 1) $10^{\circ} \mathrm{C}$; 2) $20^{\circ} \mathrm{C}$; 3) $30^{\circ} \mathrm{C}$; 4) $40^{\circ} \mathrm{C}$; 5) $50^{\circ} \mathrm{C}$.

O gel nativo, assim como a Figura 5, revelaram que há atividade de proteases de $X$. fastidiosa de citros $\left(\mathrm{X}_{0}\right)$ em temperaturas menores que $40^{\circ} \mathrm{C}$, as quais não apresentaram nenhuma atividade, capaz de ser detectada pela metodologia adotada neste trabalho, a temperatura de $50^{\circ} \mathrm{C}$.

\subsection{Atividade proteolítica em gel com substrato gelatina}

A Figura 14 apresenta os isolados de $X$. fastidiosa quanto à capacidade de produzirem proteases extracelulares em meio PW. As proteases foram verificadas em gel nativo (PAGE) em condições já definidas de ótimo de pH e temperatura, assim como tempo de incubação das amostras. 


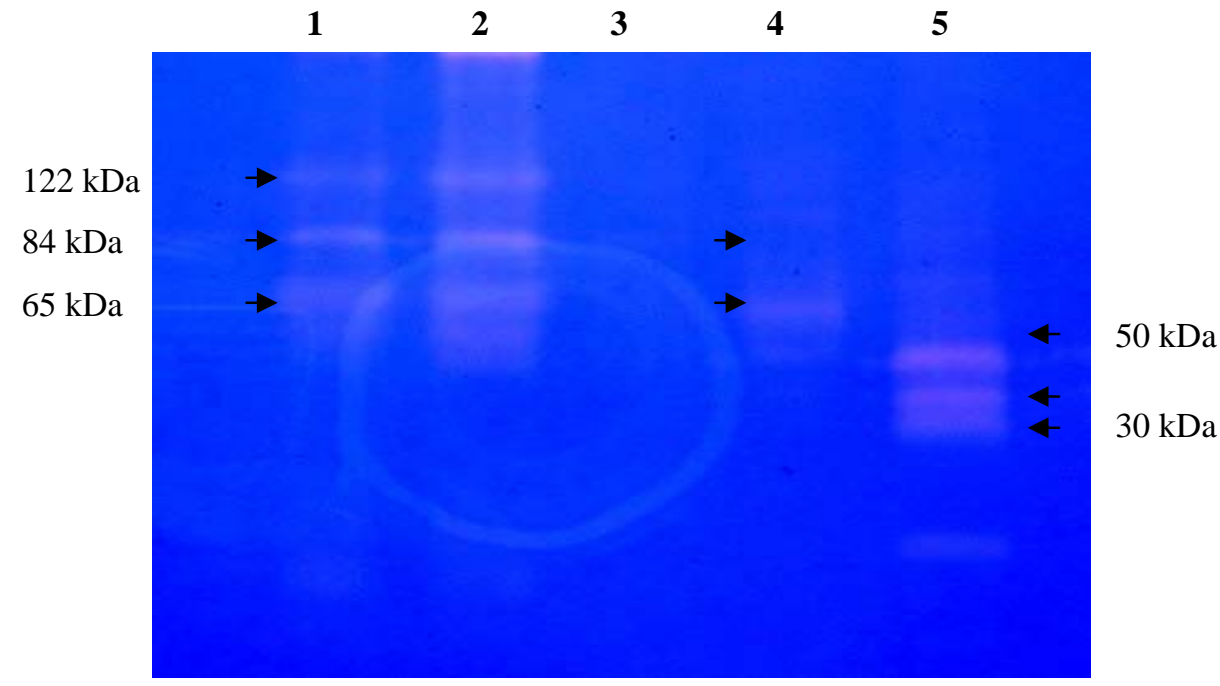

Figura 14. Proteases extracelulares dos isolados de $X$. fastidiosa em gel-nativo substrato gelatina $1 \%$ e corado com azul de Coomassie. Isolados: 1) $\mathrm{X}_{0}$ 9a5c; 2) SR3; 3) SR28; 4) 9713 e 5) Temécula.

Proteases extracelulares foram verificadas em $X$. fastidiosa de citros e videira, sendo que os isolados de citros $\mathrm{X}_{0}$ e SR3 apresentaram três bandas com massa molecular de aproximadamente 122, 84 e $65 \mathrm{kDa}$, enquanto que o isolado de videira 9713 apresentou duas bandas de massa molecular estimada de 84 e 65 kDa e o isolado Temecula 50, 38 e 30 $\mathrm{kDa}$, sugerindo que os isolados de $X$. fastidiosa de citros e videira sintetizam múltiplas proteases com massa molecular diferentes das descritas por Fry et al. (1994) para o isolado de videira (PD), o qual apresentou duas bandas de massa molecular de aproximadamente 50 e 54 kDa. Já o isolado de citros SR28 (isolado de planta assintomática) não apresentou bandas visíveis no gel nativo de eletroforese .

Os primeiros trabalhos com a bactéria $X$. fastidiosa (Hopkins, 1985) relatavam que esta não produzia enzimas pectolíticas, celulolíticas e proteolíticas em meio de cultura, parecendo ser incapaz de degradar os constituintes da parede celular, porém quando encontrada no hospedeiro estas enzimas eram produzidas. Porém a atividade de protease em meio de cultura foi demonstrada por Fry et al. (1994), sendo que a linhagem de $X$. 
fastidiosa PD, produziu duas proteases (P1 e P2) de 54 e $50 \mathrm{kDa}$, ativas em gelatina e caseína.

Outras bactérias fitopatogênicas que produzem mais de uma protease incluem Erwinia chrysanthemi (Tseng et al., 1974; Wandersman et al., 1986), Xanthomonas campestris pv. campestris (Tang et al., 1987; Dow et al., 1990) e Xanthomonas. c. malvacearum (Gholson et al., 1989).

\subsection{Efeito dos inibidores na atividade proteolítica}

Inibidores enzimáticos foram utilizados para caracterizar proteases extracelulares de $X$. fastidiosa .

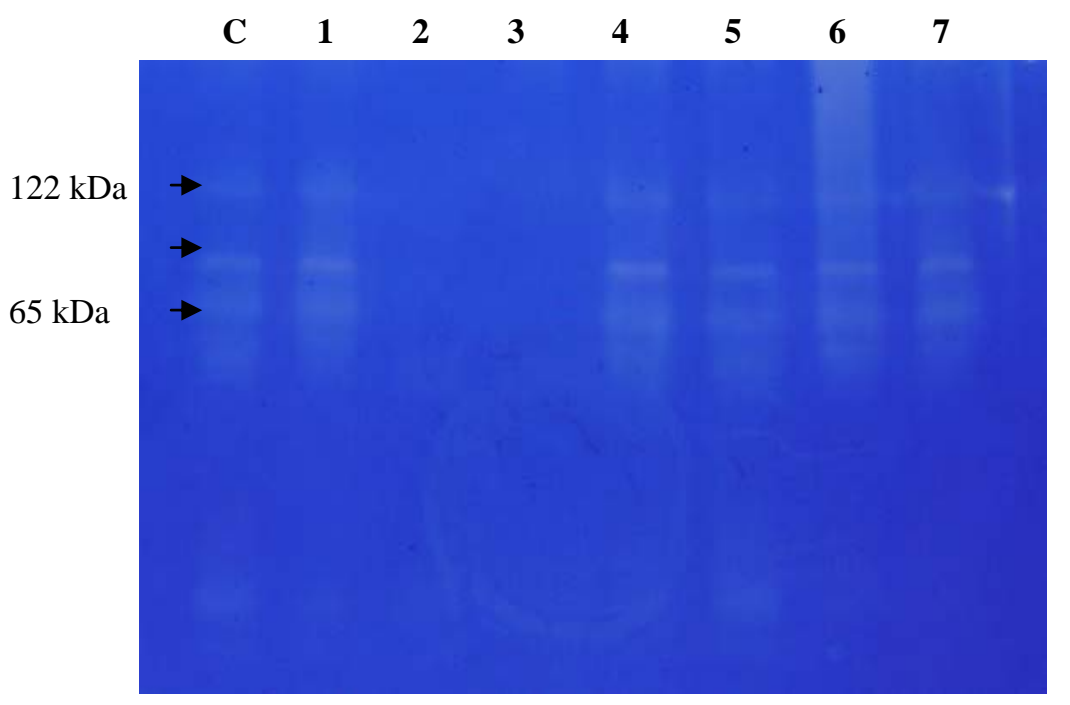

Figura 15. Perfil de proteases extracelulares de $X$. fastidiosa de citros $\left(\mathrm{X}_{0}\right)$ com inibidores (1mM): C) controle $\mathrm{X}_{0}$ - sem inibidor; 1) Leucina; 2) EDTA; 3) PMSF; 4) 3-4 DCI; 5) $\beta$-mercaptoetanol; 6) Aprotinina; 7) Pestatina A.

Proteases extracelulares de $X$. fastidiosa de citros $\left(\mathrm{X}_{0}\right)$, foram completamente inibidas por EDTA e PMSF (1mM), quando aplicadas em gel. Sugerindo que estas proteases provavelmente pertencem à classe das serina e metalo proteases, ou então são somente serina proteases que requerem íons metais para sua estabilidade e/ou aumento na 
atividade, como foi também observado por Dow (1990) que trabalhou com proteases extracelulares de Xanthomonas c. pv. Campestris.

As Figuras 16 e 17 apresentam proteases extracelulares de $X$. fastidiosa de videira e citros (respectivamente), as quais apresentaram no mínimo duas e três bandas, sugerindo a presença de múltiplas proteases.

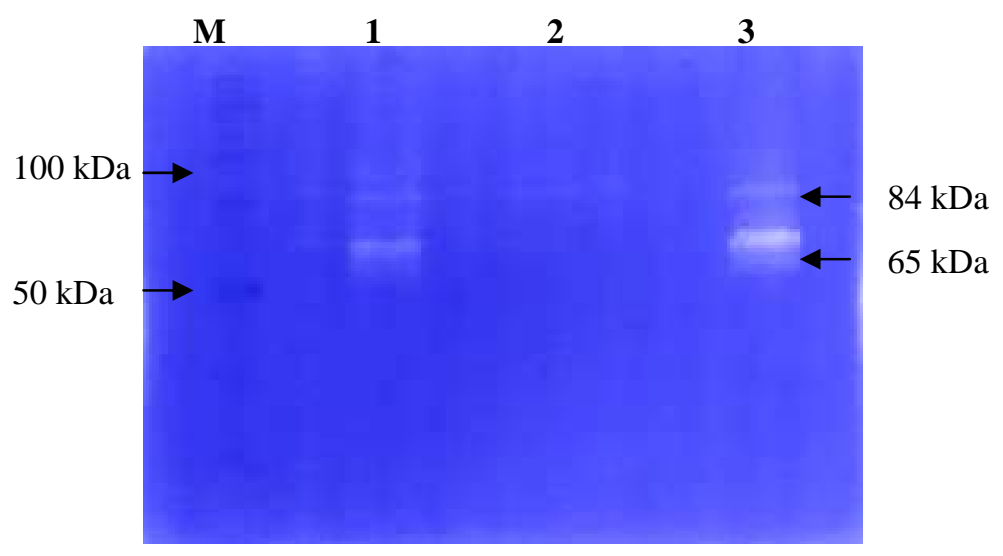

Figura 16. Detecção da atividade proteolítica extracelular de $X$. fastidiosa de videira (9713) em gel de poliacrilamida com substrato gelatina (1\%). M) marcador; 1) controle 9713 - sem inibidor; 2) 9713 + PMSF (1mM); 3) 9713 + Pestatina A $(1 \mathrm{mM})$.

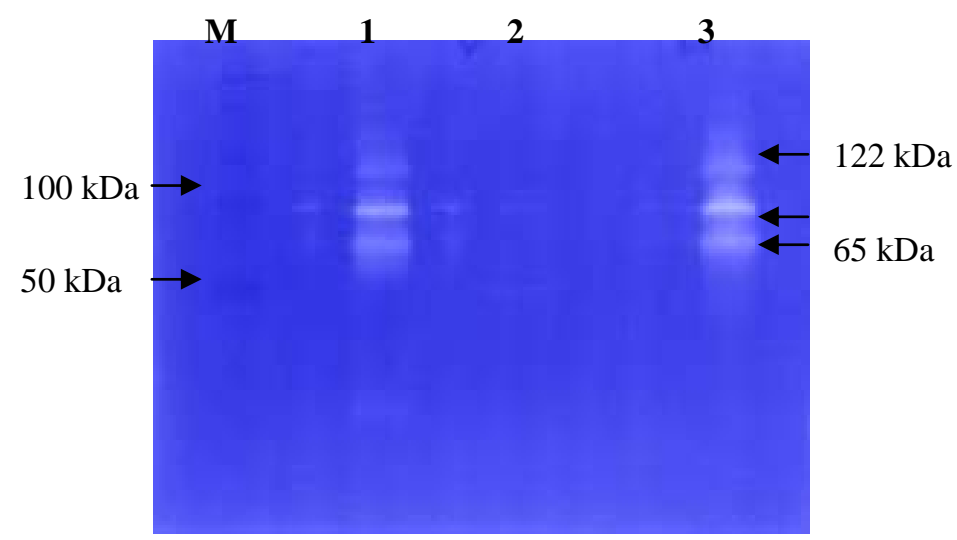

Figura 17. Detecção da atividade proteolítica extracelular de $X$. fastidiosa de citros ( $\mathrm{X}_{0}$ 9a5c) em gel de poliacrilamida com substrato gelatina (1\%). M) marcador; 1) controle $\mathrm{X}_{0}$ - sem inibidor ; 2) $\mathrm{X}_{0}+\operatorname{PMSF}(1 \mathrm{mM})$; 3) $\mathrm{X}_{0}+$ Pepstatina A $(1 \mathrm{mM})$. 
Proteases extracelulares de $X$. fastidiosa de videira (9713) apresentaram duas bandas com massa molecular (MM) estimada em 84 e 65 kDa. Proteases extracelulares de $X$. fastidiosa de citros $\left(\mathrm{X}_{0}\right)$ apresentaram três bandas que tiveram (MM) em torno de 122, 84 e $65 \mathrm{kDa}$. No entanto proteases de citros e de videira apresentaram semelhança quanto à (MM) de duas de suas proteases.

Proteases extracelulares de $X$. fastidiosa de citros e de videira foram completamente inibidas por PMSF (1mM) e quando utilizado Pepstatina A (1mM) a enzima não foi inibida e sim houve um ligeiro aumento na atividade (bandas mais intensas). 


\section{CONCLUSÕES}

Pelos resultados obtidos neste projeto de dissertação de mestrado foi possível concluir que:

- Através de ensaios enzimáticos, proteases extracelulares de $X$. fastidiosa de citros $\left(\mathrm{X}_{0}\right)$ e de videira (9713) foram caracterizadas como sendo provavelmente serina e metalo proteases, as quais foram inibidas por PMSF e 3-4 DCI (inibidores específicos de serina protease) e parcialmente inibidas por EDTA e Leucina (inibidores de metalo protease).

- Estas proteases apresentaram aumento na atividade quando incubadas com alguns cátions: sendo, para $X$. fastidiosa de citros $\left(\mathrm{X}_{0}\right)$ o $\mathrm{Ca}_{+2}$ e o $\mathrm{Na}_{+2}$ e para videira (9713) $\mathrm{Mg}_{+2}$ e $\mathrm{Fe}_{+2}$, os cátions que apresentaram maior aumento na atividade, podendo estes estarem atuando como cofatores enzimáticos.

- Proteases produzidas por todos os isolados testados hidrolisaram preferencialmente gelatina em $\mathrm{pH} 7,0$ a $30^{\circ} \mathrm{C}$.

- Todos os isolados estudados foram produtores de proteases extracelulares, porém para o isolado de citros SR28 (isolado de planta assintomática) não foi possível detectar a presença de bandas proteolíticas no gel de eletroforese nativo.

- A melhor fração para recuperação da enzima em precipitação por sulfato de amônia foi a de $90 \%$ de saturação. 


\section{ANEXO A}

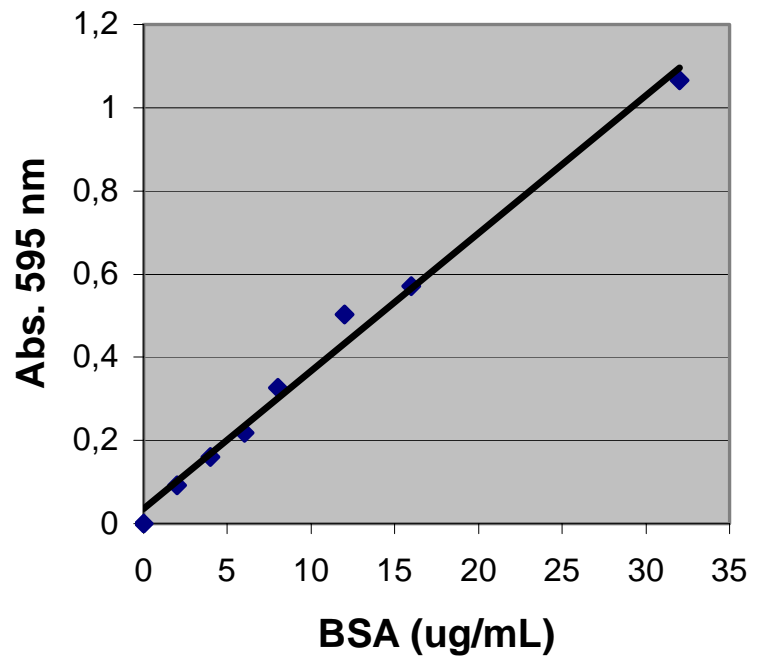

$y=0,0331 x+0,0362$

$\mathrm{R}^{2}=0,99$

- abs 595nm

Linear (abs 595nm)

Figura 1. Curva padrão de proteínas, utilizando concentrações distintas de BSA. 


\section{ANEXO B}

Tabela 1. Concentrações de sulfato de amônio utilizadas para saturação.

TABLE I

Final Concentration of Ammonium Sulfate: Percentage Saturation at $0^{\circ}$ a

\begin{tabular}{|c|c|c|c|c|c|c|c|c|c|c|c|c|c|c|c|c|c|}
\hline \multirow{3}{*}{$\begin{array}{l}\text { Initial concentration } \\
\text { of ammonium sulfate } \\
\text { (percentage saturation } \\
\text { at } 0^{\circ} \text { ) }\end{array}$} & \multicolumn{17}{|c|}{ Percentage saturation at $0^{\circ}$} \\
\hline & 20 & 25 & 30 & 35 & 40 & 45 & 50 & 55 & 60 & 65 & 70 & 75 & 80 & 85 & 90 & 95 & 100 \\
\hline & \multicolumn{17}{|c|}{ Solid ammonium sulfate (grams) to be added to I liter of solution } \\
\hline 0 & 106 & 134 & 164 & 194 & 226 & 258 & 291 & 326 & 361 & 398 & 436 & 476 & 516 & 559 & 603 & 650 & 697 \\
\hline s & 79 & 108 & 137 & 166 & $19 \%$ & 229 & 262 & 296 & 331 & 368 & 405 & 444 & 484 & 526 & 570 & 615 & 662 \\
\hline 10 & 53 & 81 & 109 & 139 & 169 & 200 & 233 & 266 & 301 & 337 & 374 & 412 & 452 & 493 & 536 & 581 & 627 \\
\hline 15 & 26 & 54 & 82 & 111 & 141 & 172 & 204 & 237 & 271 & 306 & 343 & 381 & 420 & 460 & 503 & 547 & 592 \\
\hline 20 & 0 & 27 & 55 & 83 & 113 & 143 & 175 & 207 & 241 & 276 & 312 & 349 & 387 & 427 & 469 & 512 & 557 \\
\hline 25 & & 0 & 27 & 56 & 84 & 115 & 146 & 179 & 211 & 245 & 280 & 317 & 355 & 395 & 436 & 478 & 522 \\
\hline 30 & & & 0 & 28 & 56 & 86 & 117 & 148 & 181 & 214 & 249 & 285 & 323 & 362 & 402 & 445 & 488 \\
\hline 35 & & & & 0 & 28 & 57 & 87 & 118 & 151 & 184 & 218 & 254 & 291 & 329 & 369 & 410 & 453 \\
\hline 40 & & & & & 0 & 29 & 58 & 89 & 120 & 153 & 187 & 222 & 258 & 296 & 335 & 376 & 418 \\
\hline 45 & & & & & & 0 & 29 & 59 & 90 & 123 & 156 & 190 & 226 & 263 & 302 & 342 & 383 \\
\hline 50 & & & & & & & 0 & 30 & 60 & 92 & 125 & 159 & 194 & 230 & 268 & 308 & 348 \\
\hline 55 & & & & & & & & 0 & 30 & 61 & 93 & 127 & 161 & 197 & 235 & 273 & 313 \\
\hline 60 & & & & & & & & & 0 & 31 & 62 & 95 & 129 & 164 & 201 & 239 & 279 \\
\hline 65 & & & & & & & & & & 0 & 31 & 63 & 97 & 132 & 168 & 205 & 244 \\
\hline 70 & & & & & & & & & & & 0 & 32 & 65 & 99 & 134 & 171 & 209 \\
\hline 75 & & & & & & & & & & & & 0 & 32 & 66 & 101 & 137 & 174 \\
\hline 80 & & & & & & & & & & & & & 0 & 33 & 67 & 103 & 139 \\
\hline 85 & & & & & & & & & & & & & & $0^{r}$ & 34 & 68 & i05 \\
\hline 90 & & & & & & & & & & & & & & & 0 & 34 & 70 \\
\hline 95 & & & & & & & & & & & & & & & & 0 & .35 \\
\hline 100 & & & & & & & & & & & & & & & & & 0 \\
\hline
\end{tabular}

"Adapted from "Data for Biochemical Research" (R. M. C. Dawson, D. C. Elliott, W. H. Elliott, and K. M. Jones, eds.), 2nd Ed. Oxford Univ. Press, London, 1969. Similar tables prepared for $25^{\circ}$ and $20^{\circ}$ are found in Ref. 2 (p. 76 ) and 10 (p. 303), respectively. Saturated solutions of ammonium sulfate are $3.90,4.04$, and $4.10 \mathrm{M}$ at $0^{\circ}, 20^{\circ}$, and $25^{\circ}$, respectively. Appendix $\mathrm{A}$ of Ref. 10 also presents a table for the liquid addition of miscible organic solvents or of a saturated solution of ammonium sulfate to raise an initial concentration $(\%, v / v)$ to a given higher concentration. 


\section{REFERÊNCIAS BIBLIOGRÁFICAS}

AISEN, P. Transferrin, the transferring receptor, and the uptake of iron by cells. In: Metal ions in Biological Systems. Marcel Dekker ed., New York, p.585-631.

ALBERTSSON, P.-A. e TJERnELD, F. Phase Diagrams. Methods in Enzymology, v.228, p.313, 1994.

ALBERTSSON, P.-A. Partition of Cell Particles and Macromolecules. $1^{\text {a }}$ Ed. New York: Willey Interscience, 1971, p.323.

ALFENAS, A.C.; PETERS, I.; BRUNE, W.; PASSADOR, G. C. Eletroforese de proteínas e isoenzimas de fungos e essências florestais, $1^{\text {a }}$ Ed. Viçosa/ MG, 1991, p.242.

ALFENAS , A .C., BRUNE, W. Eletroforese em gel de poliacrilamida. In: Eletroforese de isoenzimas e proteínas afins - Fundamentos e aplicações em plantas e microrganismos. Alfenas, A . C.(editor), UFV, p. 151-182, 1998b.

ANDREWS, A.T. Eletrophoresis. $2^{\circ}$ Ed. Oxford Press, Oxford, Inglaterra. 1986. 350 p.

AOKI, H.; AKAIKE, T.; ABE, K.; KURODA, M.; ARAI, S.; OKAMURA, R.I.; NEGI, A.; MAEDA, H. Antimicrob. Agents Chemother. V.39, p. 846, 1995.

AOKI, S.; ITO-KUWA,S.; NAKAMURA, K, K.; KATO, J.; NINOMIYA, K.; VIDOTTO, V. Extracellular proteolytic activit of Cryptococcus neoformans. Mycopathologia, v. 128, p. 143-150, 1994.

ATKINSON, H.J.; URWIN, P.E; HANSEN E.; MCPHERSON, M.J. Designs for engineered resistance to root-parasitic nematodes, Trends in Biotechnology, v.13, p. 369-374, 1995.

BARRAS, F.; THURN, K. K.; CHATTERJEE, A.K. Export of Erwinia chrysanthemi (EC16) protease by Escherichia coli.. Fems Microbiol. v.34, p.343-348, 1986.

BELLATO, C.M.; Messias, P.M.; Meinhardt, L.W.; Garcia, A.; Coletta Filho, H.D.; Ferraz, M.T.; Bolmström, A.; Tsai, S.M. Antibiotic, molecular and proteomic studies of Xylella fastidiosa interaction. Presented at the $10^{\text {th }}$ International Congress on Molecular Plant-Microbe Interactions. July 10-14/2001, University of Wisconsin-Madison, WI. USA. 
BERETTA, M. J. G.; HARAKAWA, R.; CHAGAS, C. M.; DERRICK, K. S.; BARTHE, G. A.; CECCARD, T. L.; LEE, R. F.; PARADELA, O.; SUGIMORI, M.; RUBIERO, I. A. First report of Xylella fastidiosa in coffee. Plant Disease, vol.80, p.821, 1996.

BERTENSHAW, G.P. \& BOND J.S. Proteases: from fertilization to cell death. TiPS, vol.21, p.319-320, 2000.

BLUM, H.; GROSS, H.J. Improved staining of plant-proteins, RNA and DNA in polyacrilamide gels. Eletrophoresis, v.8, n.2, p.93-99, 1987.

BOCCARA, M.; AYMERIC, J.L.; CAMUS, C. Role of endoglucanases in Erwinia chrysanthemi 3937 virulence on Saintpaulia ionatha. Journal of Bacteriology, vol.176, p.1524-1526, 1994.

BRADFORD, M.M. A rapid and sensitive method for the quantitation of microgram quantities of protein utilizing the principle of protein-dye binding. Analytical Biochemistry, v.72, p.248-254, 1976.

BUTLER A.M; AITON A.L; WARNER A.H., Characterization of a novel heterodimeric cathepsin L-like protease and cDNA encoding the catalytic subunit of the protease in embryos of Artemia franciscana, Biochem. Cell Biol., v.79 p.43-56, 2001.

CABIB, E. Assay for chitinase using tritiated chitin. Methods in Enzymology, v.161, p.424-426, 1988.

CAMPANHARO, J.C.; LEMOS, M.V.F.; LEMOS, E.G.M. Growth optimization procedures for the phytopathogen Xylella fastidiosa. Current Microbiology, v.46, p.99-102, 2003.

CHANG, C. J. \& DONALDSON, R. C. Xylella fastidiosa: Cultivation in chemically defined medium. Phytopathology, v.83, p.192-194, 1993.

CHAOUK, H. \& HEARN, M.T.W. New Ligand, N-(2-pyridylmethyl)aminoacetate, for Use in the Immobilized Metal Ion Affinity Chromatography Separation of Proteins. Journal of Chromatography A, v.852, p.105-115, 1999.

CHAVEZ, C. \& FLURKEY, W.H. Biospecific adsorption of peroxidase. Journal of Chromatography, v.298, p.169-171, 1984.

COLLMER, A. \& KENN, N.T. The role of pectic enzymes in plant pathogenesis, Annu Rev. Phytopathol, v.24, p.383-409, 1986.

CORNELISSEN, C.N. \& SPARLING, P.F. Iron piracy: acquisition of transferring-bound iron by bacterial pathogens. Molecular Microbiology, vol.14, p.843-850, 1994.

COSTA, A .S.; SILVEIRA, J. L.; GUIRADO, N.; MULLER, G. W. Sintomas de deficiência de molibdênio podem ser parte da resposta da planta infectada à clorose variegada do citros. Fitopatologia Brasileira, v.17, n.2, p.10, 1992. 
DAVIS, M. J.; FRENCH, W. J., et al. Axenic culture of the bacteria associated with phony disease of peach and plum leaf scald. Current Microbiology, vol.6, p.309-314, 1981.

DAVIS, M.J.; FRENCH, W.J.; SCHAAD, N.W. Axenic culture of the bacteria associated with phony disease of peach and plum leaf scald. Current Microbiology, vol.6, p.309314, 1981.

DELEPELAIRE,P. \& WANDERSMAN, C. Protease secretion by Erwinia chrysanthemi. Proteases B e C are synthesized and secreted as zymogens without a signal peptide. J. Biol. Chem, vol.264, p.9083-9089, 1989.

DOW, J. M., CHARKE, B. R., MILligAN, D. E.,TANG, J. L., DANIELS, M. J. Extracellular proteases from Xanthomonas campestris pv. campestris, the black rot pathogen. Appl. Environ. Microbiol. vol.56, p.2994-2998. 1990.

DOW, J.M.; DAVIES, H.A.; DANIELS, M.J. A metalloprotease from that specifically degrades proline/hydroxyproline-rich glycoproteins of the plant extracellular matrix. Molecular Plant-Microbe Interactions, vol.11, n.11, p.1085-1093, 1998.

DOW J.M. \& DANIELS M.J. Xylella genomics and bacterial pathogenicity to plants, Yeast vol.17, p.263-271, 2000.

DROZDOWICZ, A.G. Relações entre micro e macrorganimos. In: Tratado de Microbiologia. ROITMAN, I.; TRAVASSOS, L.R.; AZEVEDO, J.L. (Eds.), Editora Manole, vol.1, cap.3, p.61, 1991.

ELLING, L.; GOLDBAUM, R.; KULA, M.-R. Synthesis and use of PEG-oxirane for coupling to BSA and monoclonal antibodies. DECHEMA Biotechnology Conferences, v.4B, p.1135, 1990.

ENGLARD,S.; SEIFTER, S. Precipitation Techniques. In: DEUTSCHER, M. P. (ed). Guide to protein Purification, vol.182, p.285-306, 1990.

ERIKSSON, S.; JANCIAUSKIENE, S.; LANNFELT, L. Proc. Natl. Acad. Sci. USA v.92, p.2313, 1995.

FRANCO, T.T.; ANDREWS, A.T.; ASENJO, J.A. Use of chemically modified proteins to study the effect of a single protein characteristics in aqueous two-phase systems. Effect of surface hydrophobicity. Biotechnology and Bioengineering, v.49, p.300-308, 1996.

FRY, S.M.; HUANG, J.S.; MILHOLLAND. Isolation and preliminary characterization of extracelullar proteases produced by strains of Xylella fastidiosa from grapevines. Biochemistry \& Cell Biology, vol.84, n.4, 1994. 
FUJI, H. \& UEMATSU, T. Variation in the virulence of Xanthomonas oryzae (2). Difference in protease activity of $X$. oryzae isolates. Ann. Phytopath. v.41, p.337-344, 1975.

GOUGH, C.L.; DOW, J.M.; BARBER, C.E.; DANIELS, M.J. Cloning of two endoglucanase genes of Xanthomonas campestris pv. Campestris. Analysis of the role of the major endoglucanase in pathogenesis. Molecular Plant Microbe Interactions, vol.1, p.275-281, 1988.

GHOLSON, R. K.; RODGERS, C.; PIERCE, M. Extracellular proteases of Xanthomonas campestris pv. Malvacearum. (Abstr.) Phytopathology, v. 79, p. 1199, 1989.

HAMES, B. D. Gel electrophoresis of proteins : A Practical Approach $3^{\text {a }}$ Ed., Oxford University Press, Oxford, p. 13-33, 1998.

HEUSSEN, D.; DOWDLE, E. B. Anal. Biochem. Vol.102, p.196, 1980.

HILLS, B.L. \& PURCELL, A.H. Acquisition and retention of Xylella fastidiosa by an efficient vector, Graphocephala atropunctata. Phytopathology, vol.85, p.209-212, 1995.

HOPKINS, D.L. Xylella fastidiosa: A xylem-limited bacterial pathogen of plants. Annu. Rev. Phytopathol. vol.27, p.271-290, 1989.

IANNETTA P.P.M.; MCMILLAN, G.P.; SPRENT J..I.. Plant cell wall-degrading enzymes of Rhizobium leguminosarum bv. viciae: their role in avoiding the host-plant defense response. Soil Biol. Biochem. vol.29, p. 1019-1021, 1997.

KAMATH, P.M. \& WILD, L. Chromatography in polymers. In: KROSCHWITZ, J.I. Polymer characterization and analysis. Ed. J. Wiley \& Sons, p.11-30, 1990.

Collmer and N.T. Kenn, The role of pectic enzymes in plant pathogenesis, Annu Rev Phytopathol. 24 (1986) 383-409.

KAPLAN, A. H.; ZACK, J. A.; KNIGGE, M.; PAUL, D. A.; KEMPF, D. J.; NORBECK, D. W.; SWANSTROM, R. J. Virol. V.67, p. 4050, 1993.

KOSTKA, S. J.; TATTAR, T. A., et al.. Elm leaf scorch: abnormal physiology in American elms infected with fastidious, xylem-inhabiting bacteria. Can. J. For. res. vol.16, p.1088-1091, 1986.

KRISHNAN, H.B. \& PUEPPKE, S.G. Flavonoid inducers of nodulation genes stimulate Rhizobium fredii USDA257 to export proteins into the environment. Molecular PlantMicrobe Interactions, vol.6, n.1, p.107-113, 1993. 
KYOSTIO, S. R., CRAMER, C. L., LACY, G. H. Erwinia carotovora subsp. Carotovora extracellular protease: Characterization and nucleotide sequence of the gene. J. Bact. Vol. 173, p.6537-6546, 1991.

LAEMMLI, U.K. Cleavage of structural proteins during the assembly of the head of bacteriophage T4. Nature, vol.227, p.680-685, 1970.

LAINE, M.J.; HAAPALAINEN, M.; WAHLROOS, T.; KANKARE, K.; NISSINEN, R.; KASSUWI, S.; METZLER, M.C. The cellulase encoded by the native plasmid of Clavibacter michiganensis ssp. sepedonicus plays a role in virulence and contains an expansin-like domain. Physiological and Molecular Plant Pathology, vol. 57, p.221233, 2000.

LASCU, I.; ABRUDAN, I.; MURESAN, L.; PRESECAN, E.; VONICA, A.; PROINOV, I. Salting-out chromatography on unsubstituted sepharose C1-6B as a convenient method for purifying proteins from dilute crude extracts - application to horseradish peroxidase. Journal of Chromatography, v.357, p.436-39, 1986.

LEE, R. F.; DERRICK, K. S. et al. Citrus variegated chlorosis: a new destructive disease of citrus in Brazil. Citrus Industry, p.12-15, 1991.

LEHNINGER, A. L; NELSON, D.L.; COX, M.M. Princípios de Bioquímica. Ed. Sarvier, 1995.

LORITO, M.;. BROADWAY, R.M.;. HAYES, C.K; WOO, S.L.; NOVIELLO, C.;. WILLIAMS, D.L.; HARMAN, G.E. Proteinase-inhibitors from plants as a novel class of fungicides, Molecular Plant-Microbe Interactions, v.7, p.525-527, 1994.

MALAVOLTA, E. Nova anomalia dos citros: estudos preliminares. Laranja, Cordeirópolis, v.11, n.1, p. 15-18, 1990.

METHA, A., ROSATO, Y.B. Polymorphism of Xylella fastidiosa strains by RAPD-PCR and SDS-PAGE of proteins. Campinas, 2001. Dissertação (Mestrado)- Universidade de Campinas UNICAMP.

MICHAUD, D. Gel electrophorese of proteolytic enzymes. Analytica Chimica Acta, v.372, p. 173-185, 1998.

MIRCETICH, S. M.; LOWE, S. K., et al. Etiology of almond leaf scorch disease and transmission of the causal agent. Phytopathology, vol.66, p.17-24, 1976.

NEURATH H. The diversity of proteolytic enzimes. In:Beynon R.J, Bond J.S, editors. Proteolytic Enzymes a Practical Approach. Oxford, UK: IRL Press, 1989: 1-13. 
NICAUD, J.M.; MACKMAN, N.; GRAY, L.; HOLLAND, I.B. Characterization of HlyC and mechanism of activation and secretion of hemolysin from E. coli 2001. FEBS Letters, vol.187, p.339-344, 1985.

OHTAKARA, A. Viscosimetric assay of chitinase. Methods in Enzymology, v. 161, p. 426-430, 1988.

OMORI, K. \& IDEI, A. Gram-negative bacterial ATP-binding cassette protein exporter family and diverse secretory proteins. Journal of Bioscience and Bioengineering, v.95, p.1-12, 2003.

PEARSON, R.C. \& GOHEEN, A.C. Ed. Compendium of grape disease. St. Paul, Minnesota: American Phytopatologycal Society, 1990, 93p.

PONEZI, A. N. Proteases de levedura de cervejaria (Saccharomyces cerevisiae): obtenção, caracterização e aplicação em panificação. Campinas. Faculdade de Engenharia de Alimentos - UNICAMP, 1997. pg. 3-6 (tese de mestrado).

PURCELL, A. H.; HOPKINS, D.L. Fastidious Xylem-Limited Bacterial Plant Pathogens. Annual Review of Phytopathology, v. 34,p. 131-151, 1996.

RATLEDGE, C. \& DOVER, L.G. Iron metabolism in pathogenic bacteria. Annu. Rev. Microbiol., vol. 54, p.881-941, 2000.

RAWLINGS, N.D. \& BARRETT, A.J., Biochem. J., vol.290, p.205-218, 1993.

REDDY, M. N., STUTEVILLE, D. L. , SCORENSEN, E. L. Protease production during pathogenesis of bacterial leaf spot of alfafa and by Xanthomonas alfafae in vitro. Phytopathology. vol. 61, p.361-365, 1971.

ROBERTS, D.P.; DENNY, T.P.; SCHELL, M.A. Cloning of the Egl gene of Pseudomonas solanacearum and analysis of its role in pathogenicity. Journal of Bacteriology, vol.170, p.1445-1451, 1988.

RODRIGUES JL, SILVA-STENICO ME, GOMES JE, LOPES JR, TSAI SM. Detection and diversity assessment of Xylella fastidiosa in field-collected plant and insect samples by using 16S rRNA and gyrB sequences. Appl Environ Microbiol.; v.69, p.4249, 2003.

RODRIGUES NETO, J.; BERIAM, L.O. S.; KOMORI, N. Caracterização de isolados de Xylella fastidiosa de citros por eletroforese em gel de poliacrilamida/SDS. Summa Phytopathologica, (resumo), v.18, p. 46, 1993. 
ROMERO F.J; GARCÍA L.A; SALAS J.A.; DÍAZ M.; QUIRÓS L.M., Production, purification and partial characterization of two extracellular proteases from Serratia marcescens grown in whey, Process Biochemistry, v. 36, p. 507-515. 2001.

ROSSETI, V.; GONZALEZ, M. A .; DONADIO, L. C. Histórico da CVC. Clorose variegada dos citros. Donadio, L. C.; Moreira, C. S. (coord), Edição comemorativa do 15 aniversario da Estação experimental de Citricultura de Bebedouro, Apoio: Fundecitros, 1997.

RYAN, C.A. Protease inhibitors in plants - genes for improving defenses against insects and pathogens, Annual Review of Phytopathology, v. 28, p. 425-449, 1990.

SAID, S. \& PIETRO, R. Enzimas de interesse industrial e biotecnologico. Eventos Ed. 2002, 121p.

SAKAI, D. K. Loss of virulence in a protease. Deficience mutant of Aeromonas Salmonicida. Infection and immunity. v. 48, p. 146-152, 1985.

SCOPES, R.K. Protein Purification- Principles and Practice. New York: SpringerVelag, 1987

SCOPES, R.K. Protein Purification- Principles and Practice. 3. Ed., New York: Springer, 380 p., 1994.

SARATH, G., DE LA MOTTE, R. S., WAGNER, F. W. Protease assay methods. Pages 2728 in: Proteolytic Enzymes: A Practical Approach. R. J. Beynon and J.S. Bond, eds. IRL Press, Oxford. 259 p., 1989.

SUM, X. P. Isolation and characterization of na extracellular protease produced by Xanthomonas campestris pv. Zinniae and its role in pathogenesis of bacterial spot of zinnia (Zinnia elegans Jacq.) Ph.D. Dissertation. North Carolina State University, Raleigh. 78 p, 1991.

SHARMA, A.K.; PARAMASIVAM, M.; SRINIVASAN, A.; YADAV, M.P.; SINGH, T.P. Three-dimensional structure of mare diferric lactoferrin at $2.6 \AA$ resolution. Journal Mol. Biol., vol.289, p.303-317, 1998.

SHERALD, J. L. \& KOSTKA, S. J. Bacterial leaf scorch of landscape trees caused by Xylella fastidiosa. J. Arboricult. vol.18, p.57-63, 1992.

SHERALD, J. L. Bacterial leaf scorch of landscape trees. Center for Urban Ecology Information Bulletin. Washington, D. C., National Park Service, vol. 4, 1993.

SHERALD, J. L.; WELLS, J. M., et al. Association of fastidious, xylem-inhabiting bacteria with leaf scorch in red maple. Plant Dis. vol.71, p.930-933, 1987. 
SILVA da, D. M.; ONGARELLI, M. G.; HORIBE, I. Y.; PACHECO, F. T. H.; MARTINS, A . L. Técnicas de eletroforese de ácidos nucléicos e proteína. Apostila- ESALQ/USP. 1992.

SILVA, M.E. \& FRANCO, T.T. Purification of microbial $\beta$-galactosidase from Kluyveromyces fragilis by bioaffinity partitioning. Revista de Microbiologia, v.30, n.4, p.324-331, 2000.

SILVA, M.E.; PELlOGIA, C.; PIZA, F.A.T.; FRANCO, T.T. Purification of three different microbial ß-galactosidases by partitioning in Aqueous Two-Phase Systems. Ciência e Tecnologia de Alimentos, v.17, n.3, p.219-223, 1997.

SIMPSON, A. J. G.; REINACH, F. C.; ARRUDA, P. et al. The genome sequence of the plant pathogen Xylella fastidiosa. Nature, v. 406, n.13, p. 151-157, 2000.

SINHA, R. K., \& PRASAD, M. Variations in protein content due to proteolytic enzyme activities and their influence on susceptor resistant response in maize- Erwinia carotovora var. chrysanthemi host-pathogen system. Zbl. Mikrobiol. Vol.183, p. 151158. 1983.

SMITH, F. D., BERMAN, P. M., MOUNT, M. S. Characterization of an extracellular protease from Erwinia carotovora subsp. Carotovora strain EC14. (Abstr) Phytopathology. v. 77. p.122. 1987.

STRYER, L. Bioquimica. Ed. Guanabara Koogan, 3 ed. 881 p., 1992.

SVASTI, J. \& PANIJPAN, B. SDS-polyacrylamide gel electrophoresis, a simple explanation of why it works. Journal of Chemical Education, vol. 54, n.9, p. 560562, 1977.

TANG, J. L.; GOUGH, C. L.; BARBER, C. E.; DOW, J. M.; DANIELS, M. J. Molecular cloning of protease gene (s) from Xanthomonas campestris pv. Campestris: Expression in Escherichia coli and role in pathogenicity. Mol. Gen. Genet. V. 210, p. 443-448, 1987.

TOMASCHOWÁ, J.; BUCHINGER, W.; HAMPEL, W.; ZEMANOVIC, J. Purification and characterization of extracellular proteinase produced by Brevibacterium linens ATCC 9172. Food Chemistry, v. 63, p. 499-503, 1998.

TSENG, T. C.; MOUNT, M. S. Toxicity of endopolygalacturonate trans-eliminase, phosphatidase and protease to potato and cucumber tissue. Phytopathology, v. 64, p. 229-236, 1974.

WALTER, H.; BROOKS, D.E.; FISHER, D. (Ed.) Partitioning in aqueous two-phase systems. Theory, methods, uses, and applications to biotechnology. Orlando: Academic Press, 1985, 325 p. 
WANDERSMAN, C.; ANDRO, T.; BERTHEAU, Y. Extracellular proteases in Erwinia chrysanthemi . J. Gen. Microbiol. V. 132, p. 899-906, 1986.

WELLS, J. M., RAJU, B.C., HUNG, H.Y., WEISBERG,W.G., MANDELCOPAUL,L.,BRENNER,D.J. Xylella fastidiosa new-genus new-species gram-negative xylem-limited fastidious plant bacteria related to Xantthomonas spp. International Journal of Systematic Bacteriology , v.37, n2,p136-143, 1987.

WESTERMEIER, R.; BARNES, N.; GRONAU-CZY BOLKA, S. et al. Eletrophoresis in practice: a guide to theory and practice. New York: VCH, 1993. 227p.

WHITAKER, J. R. Principles of Enzymology for the Food Sciences; $2^{\circ}$ ed, New York: Marcel Dekker, Inc., 1994. 625p. Cap.: Indroduction to the hydrolases, p.387-389.

WILLIS, J. W., ENGWALL, J. K., LEACH, J. E., CHATTERJEE, A. K. Extracellular protease of Erwinia carotovora subsp. carotovora : Characterization and involvement in soft-rot pathogenesis. (Abstr) Phytopathology, vol.77, p.1736, 1987.

WILSON, T.J.G.; BERTRAND, N.; TANG, J.-L.; FENG, J.-X.; PAN, M.-Q.; BARBER, C.E.; DOW, J.M.; DANIELS, M.J. The rpfA gene of Xanthomonas campestris pathovar campestris, which is involved in the regulation of pathogenicity factor production, encodes an aconitase. Molecular Microbiology, v.28, n.5, p.961-970, 1998.

WOLF D.H. Proteases as biological regulators - introductory-remarks, Experientia, v.48, p.117-118, 1992.

WULFF, N. A. Caracterização enzimática das celulases XF-810, XF-818 e XF-2708 de Xylella fastidiosa e purificação da proteina XF-818, expressão em Escherichia coli. Tese doutorado. Esalq, 2002. 